\title{
Review of engineering, hydrogeological and vadose zone hydrological aspects of the Lanseria Gneiss, Goudplaats-Hout River Gneiss and Nelspruit Suite Granite (South Africa)
}

\author{
Matthys A. Dippenaar and J. Louis van Rooy \\ Engineering Geology and Hydrogeology, Department of Geology, University of Pretoria, Private Bag X20, \\ Hatfield, 0028, Pretoria, South Africa \\ $+27(0) 124203117$ \\ madip@up.ac.za / madippenaar@gmail.com / www.up.ac.za/geology
}

Abstract: Three major basement granites of South Africa, viz. the Lanseria Gneiss of the Johannesburg Dome Granite, the Goudplaats-Hout River Gneiss and the Nelspruit Suite, are compared in terms of existing and new geotechnical and hydrogeological data.

Typical weathering profiles based on landform and climate are deduced, denoting typical engineering and hydrogeological behaviour. Finally, the vadose zone behaviour of the basement granites are described with the aim on better understanding of the behaviour of these systems under variable saturation. Ephemeral hillslope wetlands, seepage lines and catenas are specifically addressed as associated hydrological influences, as well as the associated processes of translocation forming duplex soils and pedogenesis forming ferricrete. The final summarised findings depict low plasticity and expansiveness of granites with the most notable geotechnical influences being collapsibility, dispersive behaviour, seepage and difficult excavation. Hydrologically, secondary porosity prevails and younger structures or intrusions govern groundwater occurrence. The vadose zone comprises thick fractured rock to be included in modelling with the soil zone having saturated conductivity typically in the order of $1 \times 10^{-4}$ to $1 \mathrm{x}$ $10^{-5} \mathrm{~m} / \mathrm{d}$. 
Keywords: basement granite; saprolite; fractured aquifer; Nelspruit Suite, Johannesburg Dome Granite; Goudplaats-Hout River Gneiss; vadose zone

Abbreviations:

- ca.: circa (approximately)

- DWA: Department of Water Affairs (previously DWAF)

- DWAF: Department of Water Affairs and Forestry (now DWA)

- G-HRG: Goudplaats-Hour River Gneiss (Suite)

- JGD: Johannesburg Granite Dome

- KNP: Kruger National Park

- Ma: million years

- NGA: National Groundwater Archive

- NGRS: Ngwenyeni Northern Granites Research Supersite, KNP

- s.l. sensu lato; in the broad sense (as opposed to s.s.)

- $\quad$ s.s. $\quad$ sensu stricto; in the strict sense (as opposed to s.l.)

- SANParks: South African National Parks

- SANS: South African National Standard

- SEM: Scanning Electron Microprobe

- SGRS: Stevenson-Hamilton Southern Granites Research Supersite, KNP

- USCS: Unified Soil Classification System

- WRC: Water Research Commission

- XRD: X-Ray Diffraction

- XRF: X-Ray Fluorescence Spectroscopy 


\section{Introduction}

Numerous authors have evaluated basement aquifers in southern Africa (e.g. Botha and Van Rooy 2001; Dippenaar et al. 2009; Holland and Witthüser 2011; Titus et al. 2009; Witthüser et al. 2010). However, as a critical component of understanding the hydrological cycle, one needs to consider the behaviour of earth materials in all aspects of the hydrological cycle, which includes not only saturated conditions, but also the vadose zone, aquicludes and barriers. These all relate to the formation of the earth materials and are highly dependent on the mineralogy of the host rock, the tectonic influences causing subsequent deformation, weathering of the in-situ rock, prevailing and historical climatic conditions, geomorphological processes governing landscape development, and the intrusion of younger lithologies.

Three distinct basement granite settings have been selected based on ten years' detailed investigation in these areas and the subsequent abundance of data specifically relevant to the phreatic hydrology (behaviour as aquifers), soil properties (and shallow vadose zone hydrology) and geochemistry. These areas are:

- Lanseria Gneiss of the JGD (Gauteng Province)

- Goudplaats-Hout River Gneiss (Limpopo Province)

- Nelspruit Suite (KNP, Mpumalanga Province).

The purpose of this paper is to review and collate the data from a variety of studies within these basement granite areas, with the emphasis on addressing bulk of the important variables as envisaged in the triangle of geomechanics and the triangle of engineering geology by Bock (2006) as shown in Figure 1. The eventual aim is to address the vadose zone properties of the different basement granites in South Africa. 

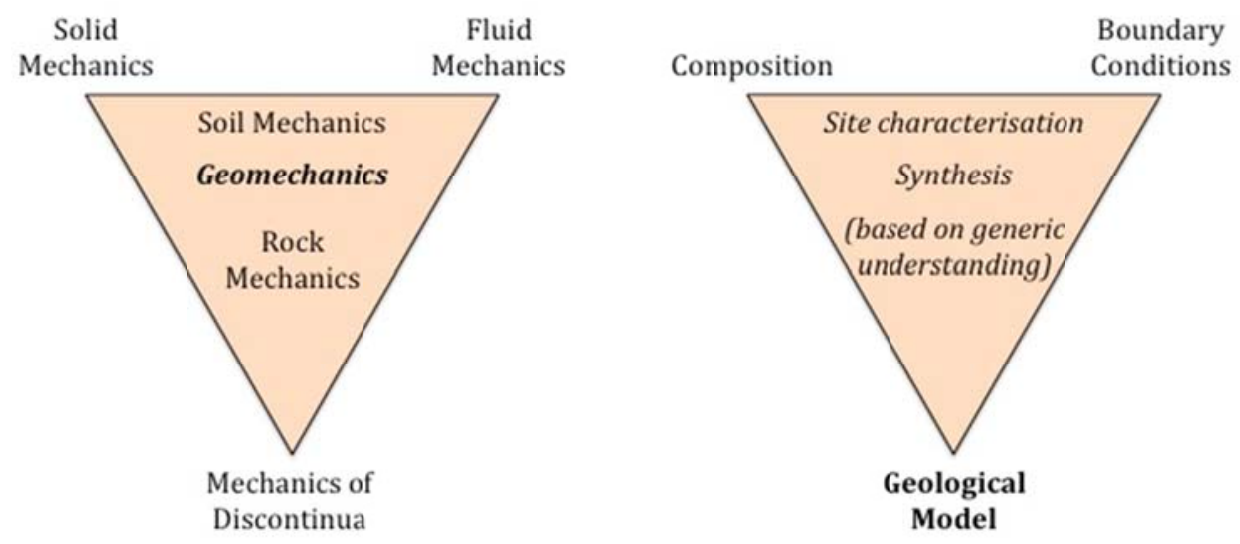

Figure 1. The triangle of geomechanics (left) and the triangle of engineering geology (right) (Bock 2006).

\section{Literature}

\subsection{Basement Granites and Weathering}

\subsubsection{Basement granite}

The term basement rock applies to any hard, crystalline or recrystallised, igneous or metamorphic rock associated with Precambrian Age, including ancient Archaean cratonic rocks (granites, gneisses, greenstones), metamorphic rocks associated with mobile belts (usually deformed and of Proterozoic age) and anorogenic intrusions of variable age (Arcworth 1987; Jones 1985; Wright and Burgess 1992; Key 1992).

Granite, from a geological point-of-view, can be considered any intrusive or hypabyssal, felsic, igneous or metamorphic rock composed of predominantly quartz and feldspar (orthoclase and plagioclase). Igneous granites (granites s.l. or granitoid rocks) typically comprise alkali feldspar granite, granite (s.s.), granodiorite and tonalite (Figure 2). 


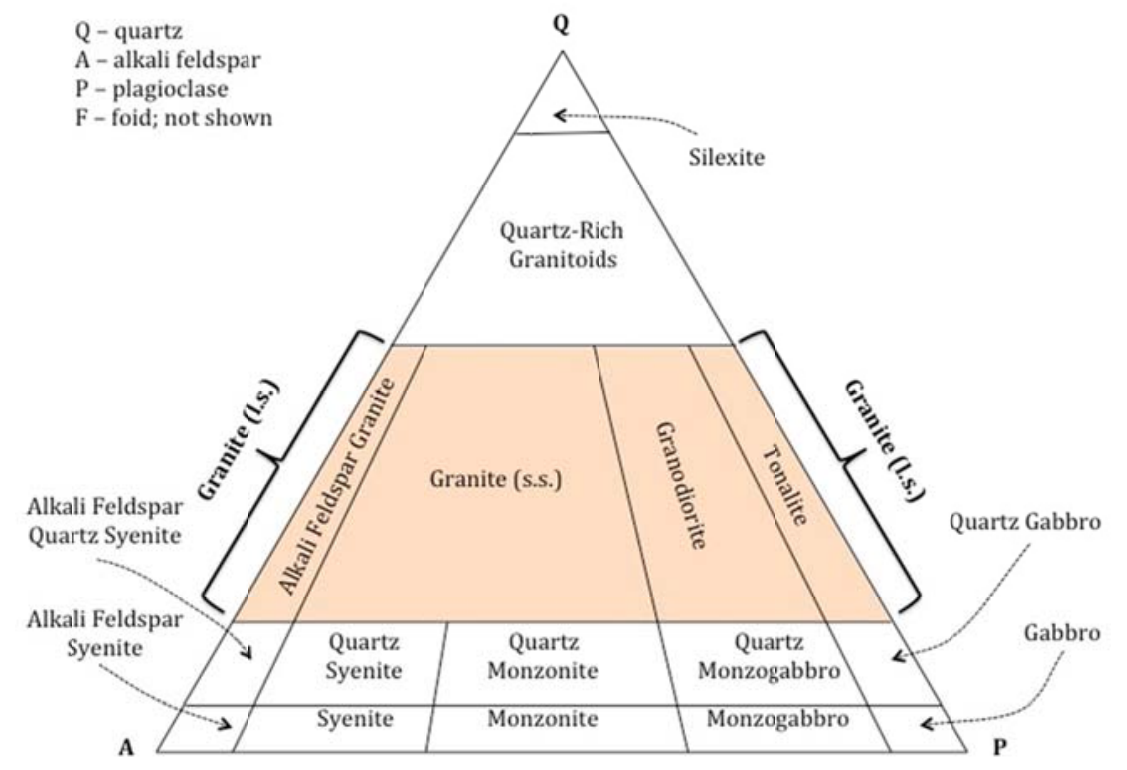

Figure 2. Upper portion of QAPF diagram indicating the plutonic igneous rocks commonly referred to as "granites" (s.l.).

Basement granite (for the purpose of this study) therefore comprises the variety of rock types as shown in Figure 3.

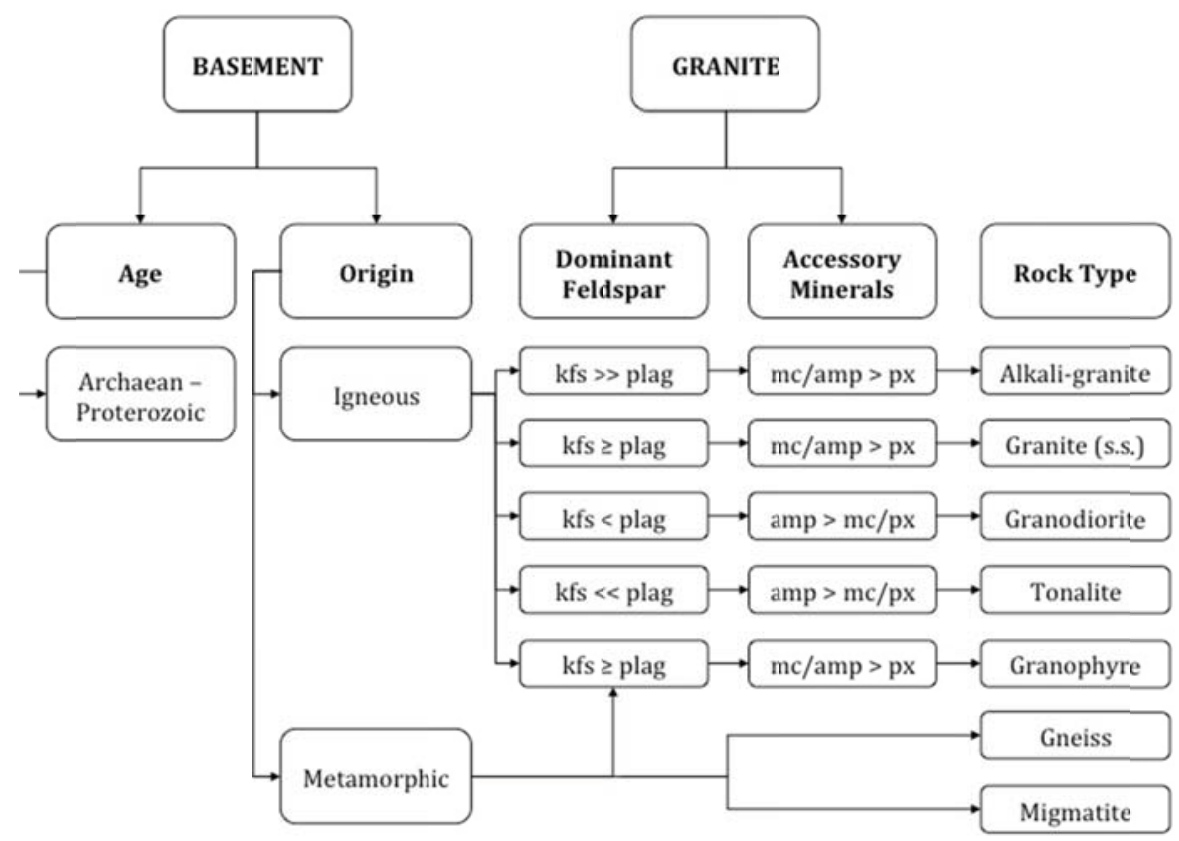

Figure 3. Classification of basement granites (kfs - potassium feldspar; plag - plagioclase; mc - mica; amp - amphibole; px - pyroxene). 


\subsubsection{Granite weathering}

A number of authors have investigated typical weathering patterns associated with granitic bedrock. Dewandel et al. (2006), for instance, considered rock mineralogy, climatic conditions (notably rainfall) and long periods of stable tectonic conditions as requirements to form thick weathering profiles. Additional to this they found that flat topography was required to enhance water infiltration and to minimise erosion of the weathering products. For areas with predominating chemical decomposition, they subdivided a basement aquifer system into:

- Laterite at surface (the possible presence of an iron/ bauxite crust)

- Saprolite (clayey material due to the in-situ chemical alteration of bedrock)

- Fissured layer (densely horizontally fissured rock)

- Fresh Basement (locally permeable bedrock).

Scarciglia et al. (2005) focused on the physical disintegration of granite in Italy rather than the chemical decomposition, placing the emphasis on climatic interpretation and an assessment of the age of the soil. Weathering processes and landforms were considered important factors, but the key roles were assigned to petrographic and mineralogical controls.

Kirschbaum et al. (2005) evaluated the granite weathering profiles in Argentina, stating that weathering "... consists of thermodynamic readjustment of these [outcropping] rocks to surface conditions." Their results showed distinct corestone development (as was also found to some extent by Scarciglia et al. (2005)) and the formation of blocks of rock due to intense fracturing. The profiles were summarised as a horizon where leaching predominates; a second where accumulation, eluviation and alteration occurs; and a third closer to the protolith characterised by fracturing and fragmentation. 
Ceryan et al. (2008) investigated the influence of weathering on granitic rocks in Turkey, specifically addressing the P-wave (primary seismic wave) velocity as an indicator of the engineering properties. In their study, they specifically also compared the percentage secondary minerals and the percentage micro-cracks and voids to discern between the different stages of weathering. Drainage conditions were found to determine the type and abundance of the different clay minerals; viz. 1:1-types in a well-drained environment and 2:1-types in poorly drained environments. This latter statement was confirmed by Sequeira Braga et al. (2002), whereby 2:1-type clays occurred more frequently under present-day wet climates, whereas the 1:1-type was more common in present-day temperate climates.

Sequeira Braga et al. (2002) evaluated the arenization (weathering leading to the sandy granite saprolite) in Portugal. They found that the weathering profiles showed vertical and horizontal heterogeneity regardless of the granite composition with corestones occurring sporadically. Sodium and calcium were found to be the most-leached elements from granitic saprolite and were ascribed to the complete alteration of plagioclase. In summary, they concluded on the importance of distinguishing between climatic versus non-climatic influences, as well as between present-day climates versus palaeoclimates.

Based on the approaches followed in international studies, soil profile development depends on historical controls (geomorphology, geotectonics and palaeosoils), presentday controls (relief and landforms, microclimate and younger soils) and the interaction between these controls as shown in Figure 4. 


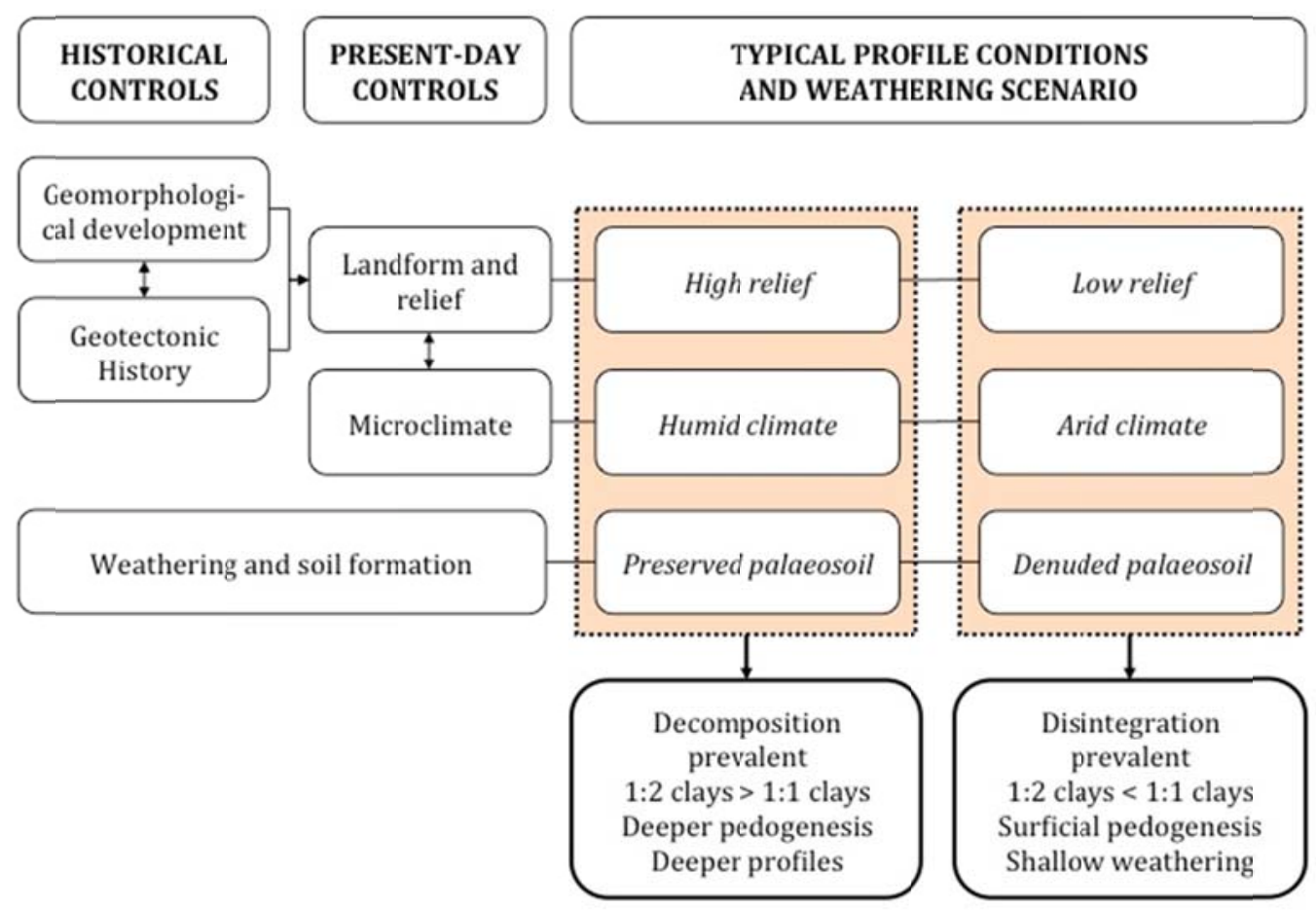

Figure 4. Historical and present-day influences on soil profile development.

Clearly one of the major determinants in the weathering profile - apart from those mentioned in Fig. 2 - is the influence of rock mineralogy. Accessory minerals occur in small quantities and can be considered to have significantly less influence on the weathering products than the main minerals. Quartz typically weathers physically to smaller grain size, as it is fairly inert chemically. However, feldspars can weather differently depending on the mineralogy, which is either the potassic end-members (orthoclase, microcline) or the calcic-sodic end-members (plagioclase). 


\subsection{South African Basement Landscapes and its Development}

\subsubsection{Geomorphological development}

The South African soil profile is fairly characteristic in that (a) transported soils are typically present, (b) a pebble horizon typically separates the transported and residual soil cover and (c) different stages of ferruginization are often present. This is mostly due to the long exposure to weathering and erosion cycles, leading to different conditions regarding water movement in the soil profile, ion movement and concentrations, and the formation of pedocretes such as ferricrete.

Intensive work were done by Partridge and Maud (1987) and King (1975) to identify these erosion cycles due to tectonic movements, sea-level changes and changing climate. After each of six recognised erosion cycles (each representing long periods of weathering and erosion), a new set of base levels was formed. The six cycles identified by King (1975) are the following:

- Gondwana planation, ca. $190 \mathrm{Ma}$

- Post-Gondwana cycle, ca. $135 \mathrm{Ma}$

- African cycle, ca. $100 \mathrm{Ma}$

- Post-African I cycle, ca. $20 \mathrm{Ma}$

- Post-African II cycle, ca. $5 \mathrm{Ma}$

- Quaternary cycle, ca. 2 Ma.

Typical landforms for granitic terrain are discussed by Venter (1986) for the central and southern KNP (Figure 5). The main distinction is based on climate and these subdivisions will be applied henceforth. 


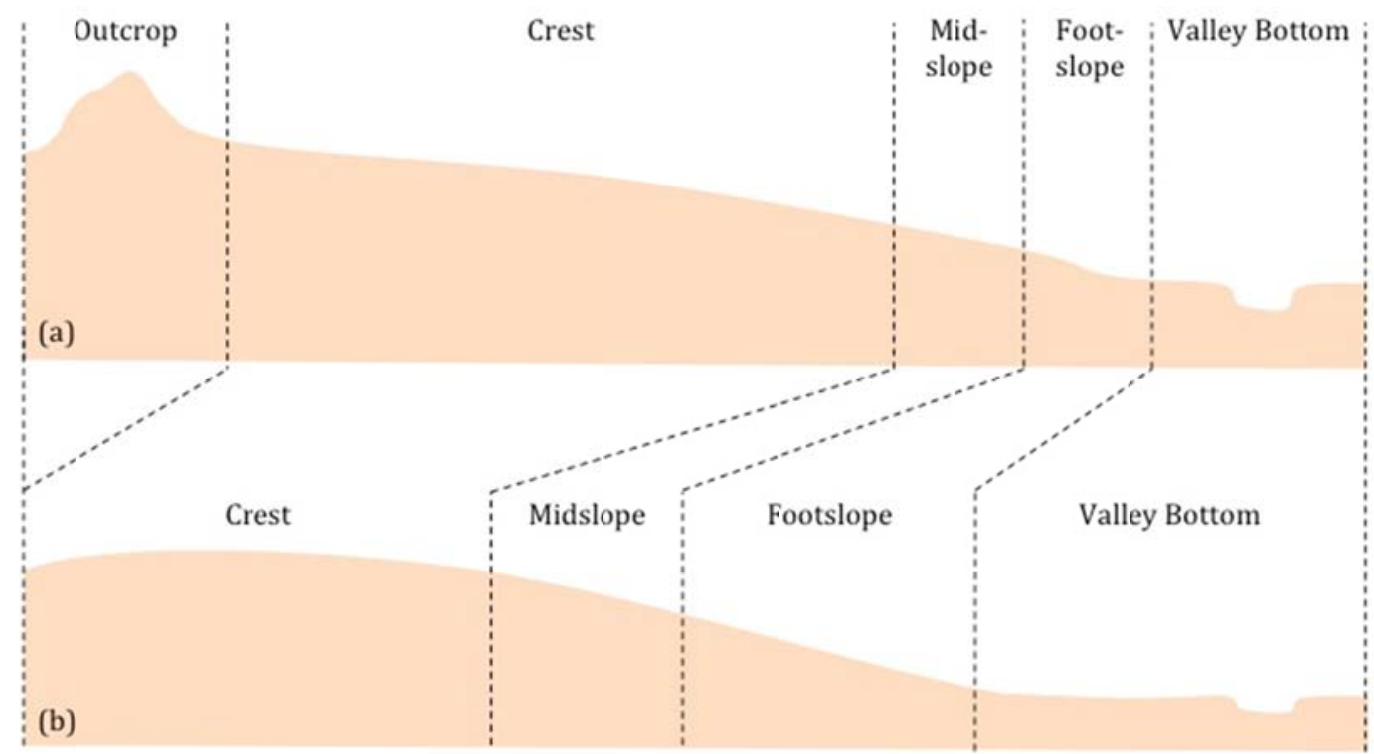

Figure 5. Typical landforms in the southern KNP (a) and central KNP (b) (Venter 1986).

\subsubsection{Tors and inselbergs}

Following extensive periods of weathering, erosion and denudation, the granite landscape in South Africa formed as it exists today with rock outcrops being typically of two broad types, viz. (Figure 6a and b):

- Tors which form as bare rock outcrops with free faces on all sides due to differential weathering and mass wasting commonly governed by jointing (e.g. Keary 2001); very often chemical weathering is induced in well jointed rock, followed by mechanical erosion of the debris, resulting in remaining corestones on surface to form the tors (e.g. Sparks 1971)

- Inselbergs which are large steep-sided outcrops forming due to parallel retreat of the bedrock slopes or resulting from deep weathering, resulting in distinct landforms surrounded by pediments (e.g. Keary 2001; Marshak 2005).

Vegter (1995) addresses regolith development in granite terrains where tors exist (Figure 6c). Tors and possibly to a lesser extent inselbergs are influenced by jointing 


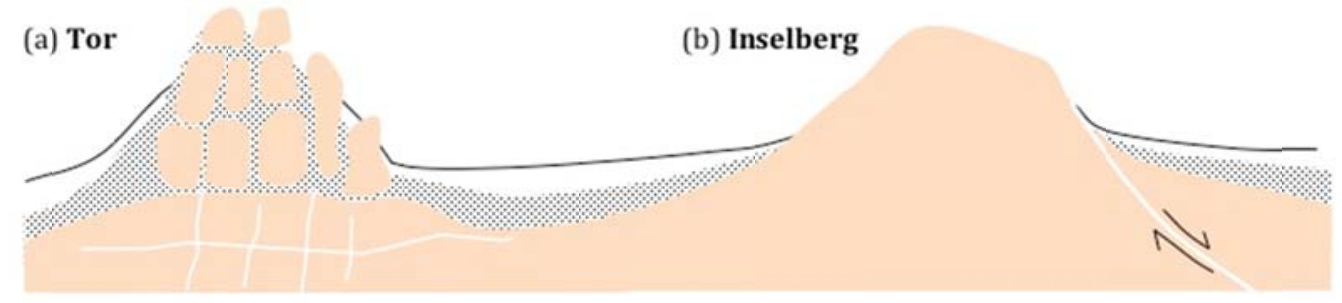

(c) Vegter's (1995) granitic regolith

Thin regolith:

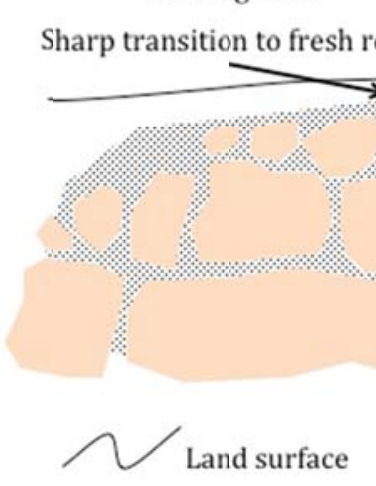

Figure 6.

(a) Tor and (b) inselberg with typical pediment cover (shaded area) and white

lines denoting joints or faults where movement is indicated; (c) Vegter's (1995) conceptual regolith development on granite.

where the more jointed part of the rock denudes to form lower lying areas between the outcrops. Inselbergs that are loaf-like and circular are termed bornhardts, as opposed to other varieties with peaked or table top crests. Large flat inselbergs are commonly termed whalebacks, with the very steep bornhardts often referred to as tortoise rocks or elephant rocks, depending on geometry.

\subsubsection{Slope hydrology and associated processes}

Fine colloids (e.g. clay minerals) and dissolved ions (depending on its solubility) are commonly mobilised in soil profiles for deposition or precipitation at another position vertically displaced in the profile or laterally downslope. Two broad categories are defined in this, namely (i) translocation or the mobilisation (leaching; eluviation) of clay 
minerals and its deposition elsewhere (illuviation) and (ii) pedogenesis or the movement of dissolved ions in water until its later precipitation on drying in more oxidizing environments.

The slope on granitic bedrock can be subdivided into a truncated weathering profile on the hillcrest and pediment with iron being leached from higher areas and accumulating as iron oxide on the lower slopes and pediments (Righi and Meunier 1995). This formation of ferricrete is fairly common in the more arid portions of South Africa underlain by granites and generally represents a seasonal perched water table. In international context, laterite is noted more typically and is the pedogenic material formed from aluminium sesquioxide. In South Africa, iron rather tends to mobilise to form ferricrete (Weinert 1980).

Well-drained to somewhat poorly drained soils often occur together in a typical toposequence (viz. changing concurrently with change in slope feature). This sequence of soil profiles can usually be superimposed on other similar topographical features, provided that the parent materials (i.e. bedrock) remain the same. The only parameters therefore influencing the soil type are drainage (given that the climate does not vary significantly) and changes in relief. This gives rise to the concept of a catena where the different soils can be distinguished based on the colours of the surficial horizons (Brady and Weil 1999).

The process of pedogenesis is influenced by the subsurface, namely that drainage occurs downslope until such a point is reached on the slope where precipitation of transported ions commences. This is then the zone of pedogenesis, leading to the formation of laterite, ferricrete, calcrete, silcrete or other pedogenic materials based on the available ions and the climatic conditions. 
Pedogenesis refers to the process through which soil become indurated as authigenic minerals precipitate within an existing material. Progressive enrichment and subsequent hardening distinguish between the typical stages of formation from an enriched soil to a highly indurated pedocrete as shown below at the hand of Fe- and Caenrichment (McFarlane 1976):

- Enriched soil (iron-rich; calcium-rich)

- Highly enriched soil (ferruginized; calcified)

- Powder pedocrete (powder ferricrete; powder calcrete)

- Nodular/glaebular pedocrete (nodular ferricrete; nodular calcrete)

- Honeycomb pedocrete (honeycomb ferricrete; honeycomb calcrete)

- Hardpan pedocrete (hardpan ferricrete; hardpan calcrete).

Glaebular commonly refers to spherical pedofeatures with notable subdivision (in soil science) into concentrically layered concretions, homogeneous nodules and striated papules (e.g. Schaetzl and Anderson 2005).

An important aspect (notably when considering bedrock as a constant and climate as a variable) is the change in hydrology due to minerals weathering differently under chemical (decomposition) and mechanical (disintegration) processes. This may results in some sort of a snowball effect where more moisture leads to more clays forming, resulting in more perching of groundwater during wet seasons, then further weathering and transformation of minerals to clays with more pedogenesis, and so forth. This is supported by Brink (1981), stating that the degree of weathering is known to influence the permeability of rocks and varies between $10^{-7} \mathrm{~m} / \mathrm{s}$ in completely weathered granitic rock and $10^{-5} \mathrm{~m} / \mathrm{s}$ in the slightly weathered zone. Unweathered granite is typically considered to be practically impervious. 
Similarly, clay minerals (with the notable emphasis on kaolinite as a common weathering product of potassium feldspar) may filtrate depending on the flow velocity. A study by Alem et al. (2013) found through tracer tests that increasing flow velocities result in further transport of clay particles and that larger particles are retained at the entrance to the medium. Kaolinite was identified as the main weathering product followed by mica in residual granitoid soils from Portugal (Viana da Fonseca et al. 2006) and is generally anticipated as the most likely clay mineral to form.

This leaching of clay minerals, or alternatively plant roots or animal burrows, can create an open soil structure (a) prone to consolidation settlement, or alternatively (b) in which coarse particles are kept in a voided skeleton by clay bridges likely to further settle through the process of collapse (Figure 7).

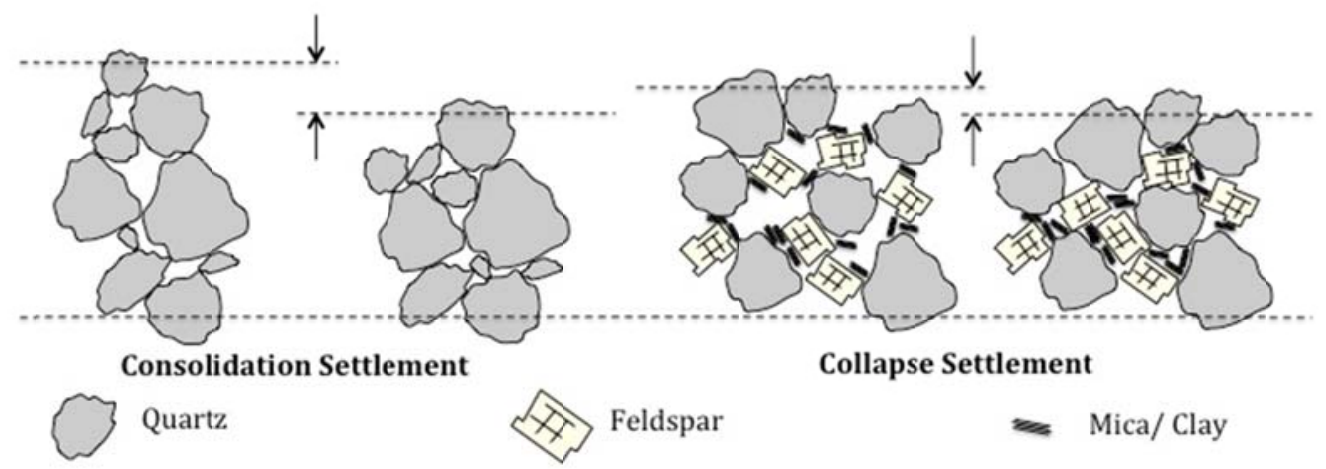

Figure 7. Mechanisms of (a) gradual consolidation settlement and (b) sudden collapse settlement.

The prior forms the characteristic eluvial and illuvial soil horizons and result, for instance, in duplex soils forming on footslopes, lessivages forming without any change in clay mineralogy, and typical catenal sequences. Typically in lessivages (and subsequently also in other clay-mobilisation settings), the leached horizon is depleted in clay minerals whereas the illuvial horizon is enriched (e.g. Zaidel'man 2007). 
Resulting from these slope hydrological processes, a number of subsurface water surface water interactions can exist. These are notable in the common occurrence of ephemeral hillslope wetlands or seepage lines and typical catena sequences in many of the South African Basement granite terrains. Catena elements comprise that specific combination of plant cover, soil, slope characteristics and slope position thought to cause and result from a relatively homogeneous water budget, and are often associated with savannah landscapes underlain by granitoid rocks in the KNP. These catenas form due to mobilisation and eluviation of clay particles and dissolved weathering products from porous upland areas, through transport under gravity and deposition on footslopes to form impermeable clay horizons, which eventually form groundwater out on surface (Cullum and Rogers 2011; Schaetzl and Anderson 2005; Venter 1986).

\subsection{Basement Aquifers}

Basement aquifers comprise the whole suite of rocks as defined earlier and which furthermore can fulfil the important function of economic water supply. Its formation and age intrinsically make these rocks - notably the granites - secondary aquifers due to the low primary porosity, the long history of tectonic and geomorphological influences and the likelihood of metamorphic textures such as gneissosity.

\subsubsection{Basement aquifers and groundwater}

Basement aquifers form a fundamental component of water supply in sub-Saharan Africa with the notable emphasis on rural domestic water supply. This has been addressed by numerous authors, including for instance Adams (2009 in Titus et al. 2009) and Witthüser et al. (2010), with further recent evaluation of groundwater supply 
and demand for a Basement aquifer in Malawi by Robins et al. (2013). This latter paper notes that basement outcrops in approximately $33 \%$ of South Africa, making it a very important potential groundwater supply. Conceptual block diagrams are additionally available in Vegter (1995). Further work has been conducted on water supply from the Nebo Granite in South Africa (Botha and Van Rooy 2001), but is not included in this review given the significantly younger age of the Bushveld Igneous Complex.

With respect to the Southern African Developing Community (SADC, and including South Africa, Lesotho, Swaziland, Namibia, Botswana, Zimbabwe, Angola, Zambia, Malawi, Democratic Republic of Congo and Tanzania), the Basement granites in north-eastern South Africa depicts very low to low aquifer productivity and moderate to high recharge potential, coupled with low to very high groundwater dependence (Villhoth et al. 2013). This dependence makes proper understanding of these aquifers important in ensuring sustainable water supply given the scarcity of perennial drainage features in South Africa.

Groundwater resource potential depends on the type of hard-rock formation, structural geology, geomorphological evolution and present-day groundwater recharge and discharge (Foster 2012), highlighting the importance of a multidisciplinary approach to data acquisition and interpretation. Optimal drilling localities are adjacent to intrusive dykes where fracturing and deep weathering prevails, as opposed to within fresh granite (Figure 8; Vegter 1995). 


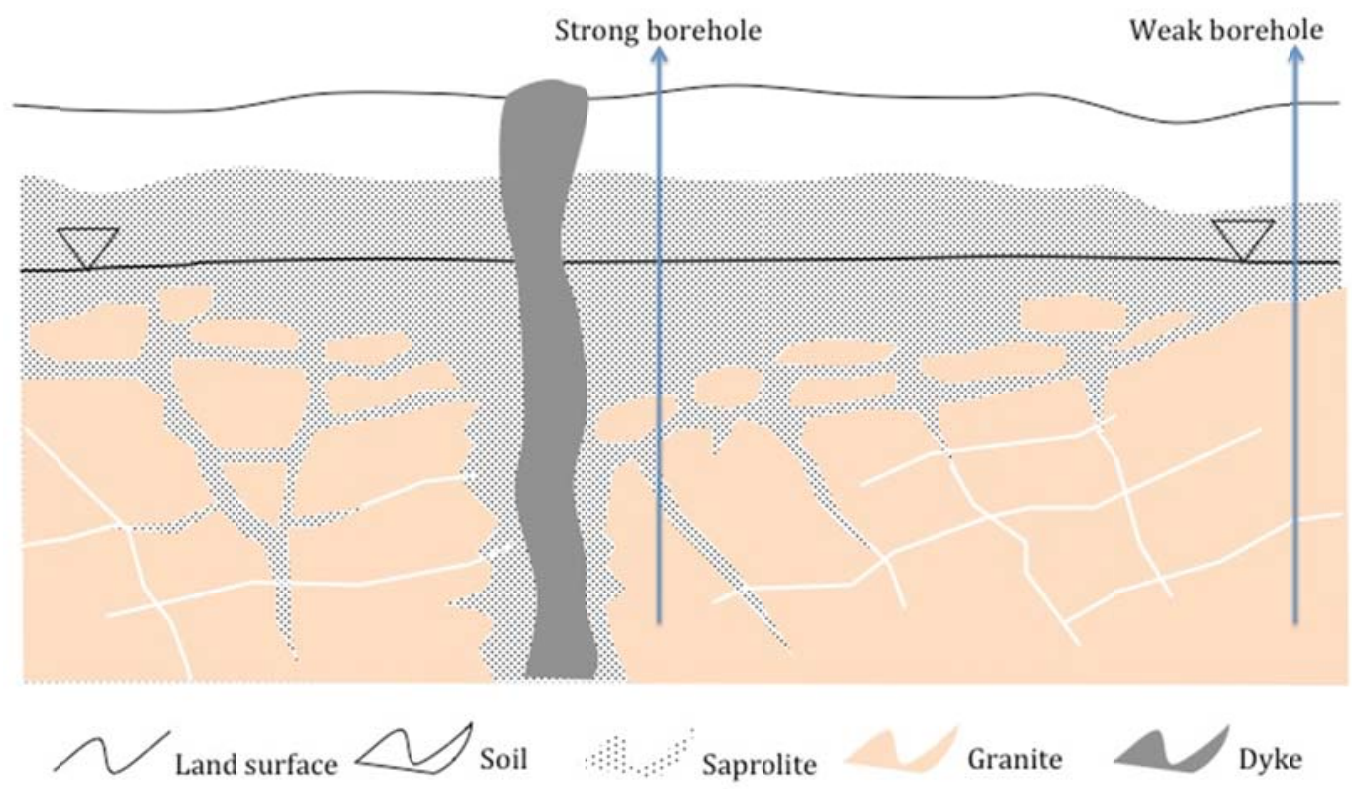

Figure 8. Influence of dykes in optimal siting of water supply boreholes in granite terrain (simplified from Vegter 1995).

\subsubsection{Hydrostratigraphy}

The term hydrostratigraphy relates primarily to the classification of earth materials in a geological context (petrology, mineralogy, structural geology and geomorphology) in order to better understand the behaviour of fluids (whether saturated or not) through these rocks and soils, and to expand this understanding to regional scale. For the purpose of this paper, it therefore includes the likelihood of water infiltration from surface, the vadose and phreatic zones, and the possible presence of aquicludes or aquitards.

Lithofacies types refer to sedimentary properties (particle size distribution, texture and fabric), which directly relates to hydraulic properties (e.g. hydraulic conductivity and porosity), resulting in the term hydrofacies, which relate to homogeneous anisotropic units of hydrogeological similarity (Heinz and Aigner 2003). These combined compile 
the hydrostratigraphy of a given region with knowledge regarding the hydraulic behaviour of different stratigraphic units.

The importance of hydrostratigraphy and means of standardizing and simplifying classification of hydrostratigraphic units are addressed in a number of recent studies (e.g. Allen et al. 2007; Angelone et al. 2009; Heinz and Aigner 2003). Application is mostly in sedimentary and unconsolidated aquifers with some recent development in fractured and confined aquifers and vadose zone assessments. Hydrostratigraphy is based around increasing scale of investigation as shown at the hand of sedimentary environments (Heinz and Aigner 2003):

- Hydrogeochemistry - basic transport processes at particle scale

- Hydrofacies - depositional dynamics at strata scale

- Hydraulic Connectivity - geomorphological dynamics at depositional elements scale

- Aquifer Compartments - environmental system dynamics at facies bodies scale

- Aquifer Storeys - process dynamics at sequence scale

- Hydrostratigraphy - basin dynamics at basin fill scale.

Hydrostratigraphy will henceforth be slightly redefined to include regional variation of earth materials to include the complete phreatic and vadose zones, as well as all forms of aquitards, aquicludes and aguifuges, as well as all components of the rock cycle. However, the focus will henceforth be on understanding the vadose zone component.

\subsection{Typical Material Successions}

Foster (1984) and Foster (2012) present typical hydrogeological characteristics superimposed on a typified weathering profile for crystalline basement in south-eastern 
Africa, as well as the weathering profile for granite in humid Ivory Coast as proposed by Koita et al. (2013). Although the climate inevitably results in more decomposition and deeper profiles, the proposed horizons provided are consistent with other terminologies, and include:

- Soil

- Saprolite or altorite

o Alloterite (clayey material; typically kaolinite-rich)

o Isalterite (highly weathered with coarse granite debris

- Fissured layer (slightly weathered fissured granite)

- Fractured fresh granite.

These, correlating to typical descriptions used by engineering geologists in South Africa, pose a number of contradictions without any party being in the wrong. Different investigations are required for different purposes, and subsequently material successions may vary. Hydrologically, the profile depicted by Foster shows a zone of higher hydraulic conductivity in what the engineering geologist describes as residual granite (in-situ weathered to a state beyond recognisable as the host rock) and weathered granite. This is also the zone above which water perches as fresh bedrock is often of very low hydraulic conductivity, and in which - due to the perched water tables - pedogenetic materials form. The pebble marker here denotes a very typical South African stone line, which characteristically denotes the contact between transported and in-situ formed soils (Figure 9). 


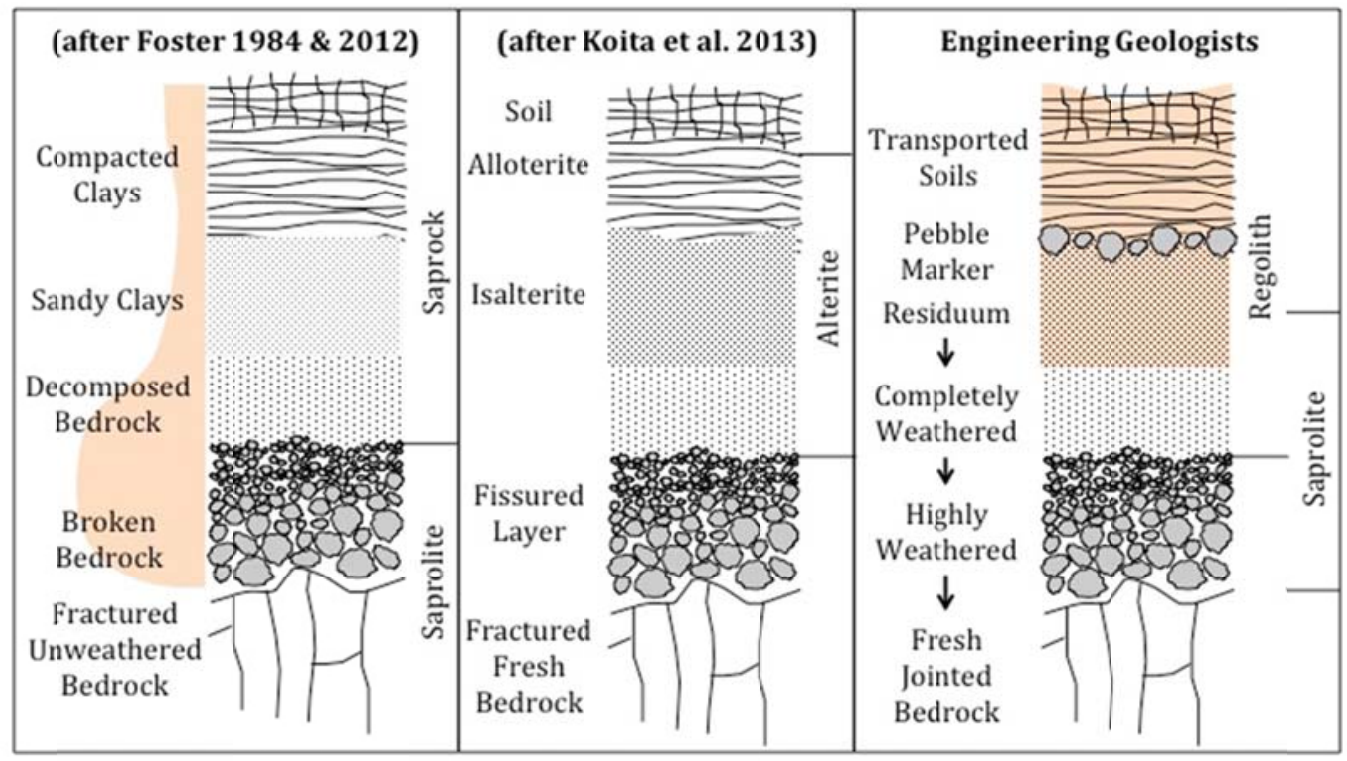

Figure 9. Typical hydrogeological characteristics and typical engineering geological succession (shaded area denoting typical position of pedocretes).

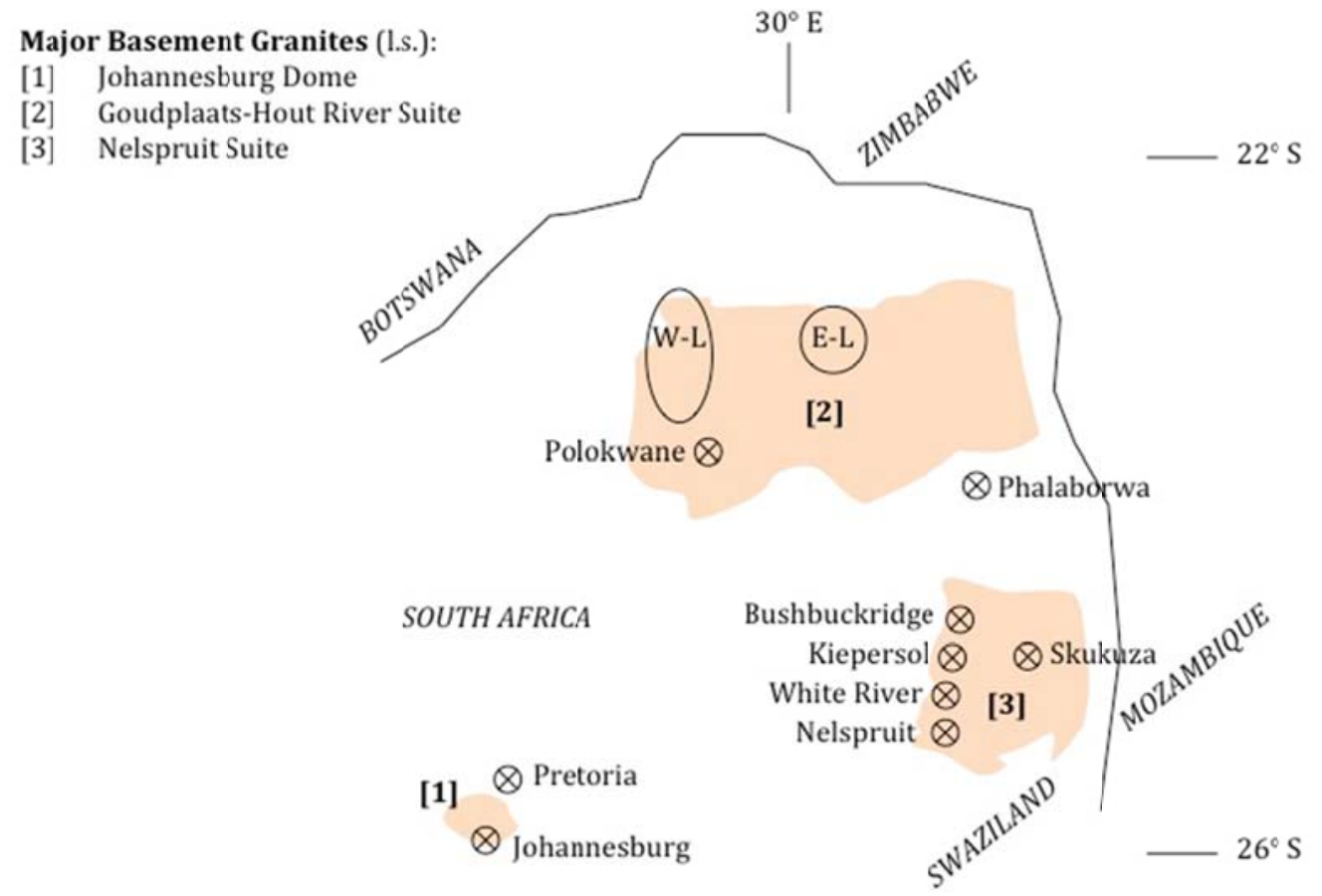

Figure 10. Some major basement granites of Gauteng, Limpopo and Mpumalanga Provinces in South Africa, excluding younger intrusive plutons and smaller inliers (adapted from Johnson et al. 2006). 


\section{Materials and Methods}

\section{1. $\quad$ Study areas}

The study areas are selected to address three major basement granite areas in the temperate areas of South Africa (Figure 10). Smaller plutons, localised variations in lithologies and surrounding rock types are not shown. Sampling positions are indicated by means of towns, cities or regions (e.g. W-L and E-L denoting western and eastern regions of Limpopo Province).

The Johannesburg Dome underlies a vast area in South Africa's economic node, Gauteng. Urban development in this area emphasises the importance of understanding water behaviour, notably given the urban infrastructure that can easily be influenced by water. The Goudplaats-Hout River Gneiss is included as an equally important rural development node where groundwater is often the sole water supply. The Nelspruit Suite is included as undisturbed study areas within the KNP, as well as the densely developed Bushbuckridge area.

For simplification, the study areas will be labelled as follows:

- Lanseria Gneiss - of the Johannesburg Dome, underlying Midrand and the northern suburbs of Johannesburg

- Goudplaats-Hout River Gneiss - subdivided into W-L (Western Limpopo in the vicinity of Vivo) and E-L (Eastern Limpopo in the vicinity of Giyani)

- Nelspruit Suite - in the area of the SGRS, KNP. 


\subsection{Investigation approach}

This study is the culmination of approximately 10 years' work - some published in journals and others in research or consulting reports - focused solely around Basement granite terrains in the north-eastern portions of South-Africa. Historical and new data from a variety of geological, engineering geological, hydrogeological and vadose zone hydrological investigations have been collated to deduce common behaviour for different basement granites in different climatic-geomorphological settings in South Africa. The data do not always represent the exact same parameters; however, incorporation of different data sets may supply new knowledge to the understanding of these systems in different climatic and geological settings and may reduce bias resulting from the interpretation of small, localised datasets.

The case studies are presented in four sub-sections: (1) geology, (2) soil profile and indicator test results, (3) geomorphology and landforms, and (4) hydrostratigraphy, incorporating available literature, published data and selected additional data collected from a variety of recent studies.

\subsection{Investigation techniques}

Standard geotechnical, hydrogeological and vadose zone assessment techniques were applied for the respective study areas. The methods detailed below were employed to varying degrees in some or all of the instances and supply an informative bulk database. Given the elaborate methodology applied to all study areas, standard guidelines were used with minimal deviation to ensure replication of results. Short summaries of the methods are supplied and elaboration can be obtained from the cited references. 
Soil profiles were recorded according to moisture, colour, consistency, soil structure, soil type (texture) and origin as per SANS 633 (SABS 2012a) with the original engineering geological investigations conducted according to SANS 634 (SABS 2012b) or the generic specification by the National Department of Housing (2002). In the original draft versions, these standards applied to any investigation, although the focus has since been moved to dolomite land specifically. Other older guideline documents (e.g. Brink and Bruin 2001; Jennings et al. 1973; SAICE 2010) elaborate on the methods and/ or formed the basis of these standards and its application can be well extended beyond solely dolomite land.

Foundation indicator laboratory analyses are conducted to determine the particle size distribution and the Atterberg limits of selected samples. The prior depicts the percentage abundance of different particle sizes on cumulative distribution plots, whereas the latter relates the engineering behaviour of soils to moisture contents. In many instances, the Unified Soil Classification System's (USCS's) soil class is also supplied.

XRF and XRD analyses were conducted to address the chemical and mineralogical compositions of different horizons for comparative purposes, notably with respect to composition of the granite bedrock, alterations due to weathering and changes in composition due to translocation and leaching processes.

Where available, photographs were taken of thin sections under petrographic or reflecting light microscopes. Limited additional samples were photographed and interpreted by means of scanning electron microprobe. 
Limited double ring infiltration (e.g. Jenn et al. 2007; Reynolds and Elrick 1986) or auger hole percolation tests (SABS 1993) were conducted in some of the areas to infer saturated vertical hydraulic conductivities for site materials. In both instances, late-time steady state time-drawdown data are used to calculate an infiltration or percolation rate in distance per time. Under the assumption that the soils are saturated when steady state conditions are encountered, and under an assumed hydraulic gradient (i) of unity, the rate of infiltration or percolation $(q)$ equals the hydraulic conductivity $(K)$ according to $q=K i$.

\section{Results}

\subsection{Geology}

Available XRD and XRF data are shown in Appendix A and are discussed for each area.

\subsubsection{Lanseria Gneiss}

Five distinct varieties exist within the JDG, including the Lanseria Trondhjemite Gneiss (ca. 3 340), which forms the focus point of this study and makes up the northern half of the dome. The southern half of the dome comprises four smaller outcrops, is marginally younger in age and varies in composition between tonalitic gneiss, granodiorite and porphyritic granodiorite (Robb et al. 2006). Eight samples analysed for highly weathered to fresh granite from Midrand (Gauteng) show approximately 29 - 51\% (37.3\%) qtz, 27 - 40\% (33.3\%) plag, 5 - 39\% (19.0\%) kfs and the remainder accessory muscovite or kaolinite. This classifies the Lanseria Gneiss, on average, as granodiorite in composition. 


\subsubsection{Goudplaats-Hout River Gneiss (G-HRG)}

The G-HRG Suite range in age from 3600 to 3200 Ma and comprise a wide range of granitoid gneisses. The gneisses are massive to layered, leucocratic to dark grey and vary in grain-size from fine-grained to pegmatoidal. The area of interest - around Polokwane - is underlain by homogenous, light grey, medium-grained biotite gneiss (syenogranitic in composition) with occasional distinct leucocratic bands resulting from local incipient anatexis. Younger granitic intrusions into but not forming part of the GHRG include the Duivelskloof Leucogranite, Shamriri Granite, Turfloop Granite, Matok Granite, Moletsi Granite, Matlala Granite, Utrecht Granite and Mashashane Suite (Robb et al. 2006).

\subsubsection{Nelspruit Suite}

Granitoid rocks in the KNP include, from the most recent to the oldest (Robb et al. 2006; Barton et al. 1986) include:

- Phalaborwa Complex; syenite (ca. $2050 \mathrm{Ma}$ )

- Muscovite-bearing Pegmatites; granite (s. s.; ca. 2200 Ma)

- Granodiorite Plutons; granodiorite, granite, trondhjemite (s. s.; $2650 \pm 50 \mathrm{Ma}$ )

- Nelspruit Suite/ Nelspruit Granite-Migmatite Complex; granodiorite, granite, migmatite (s. s.; ca. $3200 \mathrm{Ma}$ )

- Tonalitic and Trondjemitic Gneisses; tonalite, trondhjemite (ca. $3500 \mathrm{Ma}$ ).

The Stevenson Hamilton Southern Granites Research Supersite (SGRS, one of four identified as per Smit et al 2013) falls in the Nelspruit Granite-Migmatite Complex, which is also known as the Nelspruit Batholith or Nelspruit Suite. This forms part of the Mesoarchean intrusion emplaced ca. 3200 - 2800 Ma with at least one pluton (Cunning 
Moor Tonalite pluton, although not yet identified in the KNP) emplaced around 2800

Ma. The Nelspruit Suite has distinctive textural varieties such as gneiss, porphyritic granite (s. s.) and two other smaller plutons with the coarse-grained, strongly porphyritic predominantly granodiorite or quartz monzonite being most prevalent. These granites are generally greyish to pinkish in colour and comprise quartz, plagioclase, microcline perthite and biotite where the K-feldspar forms phenocrysts. Particularly along the margins of the batholith one finds the gneiss to be migmatitic that rarely shows regional orientation (Robb et al. 2006; Barton et al. 1986).

XRD and XRF results from the SGRS are shown in Appendix A. The flatter areas of the batholith have much higher quartz content (granite s.s.) than the outcropping tors and inselbergs. Four such major outcrops were sampled and analysed and have localised varying composition of the greater batholith as follows:

- Matekenyane (inselberg) is composed of a coarse-grained massive leucogranite phase as well as darker bands of melanogneiss. In terms of composition, the leucogranite (SG15F) is granite (s.s.) comprising approximately a third each of microcline, plagioclase and quartz in its fresh state. The darker melanogneiss bands (SG15W) comprise muscovite and plagioclase with lesser kaolinite (potentially due to weathering of feldspar) and accessory microcline and hornblende. The outcrop forms a large flat inselberg ("whaleback") with a circular form and rising from the flat peneplains. Texturally it appears to be migmatitic.

- The outcrop at the Stevenson Hamilton memorial (SG03) is much more pronounced as a bornhardt inselberg with steep sides as the major landform with evidence of joint controlled tor formation around the major outcrops. Mineralogically it comprises quartz, plagioclase and microcline with accessory biotite and is classified as granite (s. s.). 
- The outcrop in the southeast of the study area (SG73) also resembles a bornhardt with joint controlled tor formation around the major inselberg. The granite here is distinctly foliated into gneiss with a tonalitic to trondjemitic composition, the latter referring to the absence of mafic minerals in the general composition. Plagioclase followed by quartz is the major constituent with accessory biotite and microcline.

- The tor along the western boundary of the study area comprises a number of suboutcrops. This tor possibly contains chemically and texturally distinct granite. Also distinctly foliated, it is composed of (SG80) quartz and plagioclase with lesser microcline and accessory biotite and diopside and therefore has a generally granodioritic composition.

- The batholith underlying the flatter portions of the site is composed roughly of more than 50\% quartz, 20 - 25\% microcline, $15-20 \%$ plagioclase and possible accessory muscovite. The Nelspruit batholith is therefore granitic (s. s.) in composition.

\section{2. $\quad$ Soil Profile and Indicator Test Results}

Available indicator test results are shown in Appendix B and are discussed below.

\subsubsection{Lanseria Gneiss}

Typical profile successions for the Lanseria Gneiss are as follows (summarised in Table 1):

- Silty sandy colluvium (topsoil) from surface, often pinholed and well-leached if not vegetated; this often grades into a thicker silty sandy colluvium, often 
Table 1. Thicknesses of typical horizons per profile type for the JDG per landform (from Van Rooy and Dippenaar 2008) and for an ephemeral hillslope wetland.

\begin{tabular}{|c|c|c|c|c|c|c|}
\hline Type & Population n & Colluvium & $\begin{array}{c}\text { Pebble } \\
\text { Marker }\end{array}$ & $\begin{array}{c}\text { Residual } \\
\text { Granite }\end{array}$ & $\begin{array}{c}\text { Completely } \\
\text { Weathered }\end{array}$ & $\begin{array}{c}\text { Granite } \\
\text { Bedrock }\end{array}$ \\
\hline Hillcrest & 8 & 0.59 & 0.15 & - & - & - \\
\hline Upper slope & 41 & 0.42 & 0.24 & - & - & - \\
\hline Midslope & 15 & 0.33 & 0.23 & - & - & - \\
\hline Lower slope & 40 & 0.36 & 0.23 & - & - & - \\
\hline Floodplain & 2 & - & - & - & - & -1.15 \\
\hline Wetland & $6-13$ & 0.56 & $(0.71)$ & 1 & & - \\
\hline
\end{tabular}


yellowish grey to pale brown, and which typically exhibits collapsible soil fabric (typically absent to $<1.00 \mathrm{~m}$ thick)

- Various amounts of gravel, pebbles and cobbles, typically comprising quartz and weathered granite, in a matrix of silty sand, forming a characteristic pebble marker (occasionally absent or poorly defined to $<0.50 \mathrm{~m}$ thick)

- Reddish brown to yellowish brown, slightly clayey silty sandy residual granite, structure more intact although occasionally pinholed to voided, and characteristically mottled to ferruginized (typically $<0.50 \mathrm{~m}$ thick)

- Ferricrete, if present, forming typically within the pebble marker or residual granite with the origin of the soil being unclear when encountering hardpan stages of formation (absent to $<0.40 \mathrm{~m}$; thickness often undetermined due to impenetrability by means of backhoe)

- Pinkish to yellowish white or white, often streaked, stained or mottled black, completely weathered granite with gravelly silty sandy texture and often with distinct foliation and/ or remnants of Fe-stained joint surfaces (typically $<1.00$ m grading gradually into highly weathered bedrock)

- Fresh jointed bedrock.

44 residual granite samples were addressed in terms of its indicator properties (Dippenaar et al. 2006). An additional 107 transported and ferruginized soil profiles from historical engineering geological investigations on the Johannesburg Dome were evaluated in terms of the landform on which the profiles were described, as well as the typical index properties (Van Rooy and Dippenaar 2008). Data from these studies are shown (with permission from the authors) in the Appendix B.

\subsubsection{Goudplaats-Hout River Gneiss (G-HRG)}


Soil profiles in the G-HRG are more variable given the aerial extent of the gneiss, as well as distinct local variations, climatic influences and intrusions. No laboratory testing formed part of the study.

\subsubsection{Nelspruit Suite}

Five typical soil profiles (excluding alluvium) were identified and are labelled according to the characterising surface material. All data are contained in Table 2 and Appendix B and are discussed below. The number of profiles described per type is supplied in brackets $(n)$ and the materials are labelled according to the characteristic shallow materials.

Type 1: brown sandy colluvium $(n=15)$. All horizons are sandy with the pebble marker and residual granite tending more towards gravel-sand. Clay contents are very low for all horizons with a harmonic mean of $4.9 \%$. Plasticity indices calculated are very low for all horizons, ranging between zero (not plastic) to 6\%. Colluvium is classified as SM (silty sand) according to the Unified Soil Classification System (USCS), followed by SWSM (well-graded sand - silty sand) for the pebble marker and mostly SM for residuum and weathered granite. Typical material succession is as follows:

- Colluvium - slightly moist, light to dark brown (speckled orange)/ (light) orange or reddish brown/ occasionally greyish brown, (pinholed; with krotovinas), gravelly or clayey silty SAND

- Pebble Marker - slightly moist, orange brown, pinholed with open root channels, gravelly silty SAND with scattered fine to medium quartz gravel

- Residual Granite (occasionally reworked) - slightly moist, (yellowish) brown, (gravelly) silty SAND with abundant, fine to medium, subangular quartz and feldspar gravel 
Table 2. Thicknesses of typical horizons per profile type for the SGRS near Skukuza area in Kruger National Park.

\begin{tabular}{|c|c|c|c|c|c|c|}
\hline Type & Profile & Colluvium & Pebble Marker & $\begin{array}{l}\text { Residual } \\
\text { Granite }\end{array}$ & $\begin{array}{l}\text { Completely } \\
\text { Weathered }\end{array}$ & $\begin{array}{l}\text { Granite } \\
\text { Bedrock }\end{array}$ \\
\hline \multirow{17}{*}{$\begin{array}{l}\text { Brown Sandy } \\
\text { Colluvium }\end{array}$} & SG08 & 0.2 & $\mathrm{X}$ & 0.45 & $\mathrm{X}$ & $>0.60$ \\
\hline & SG12 & 0.69 & $\mathrm{X}$ & 0.69 & $>0.79$ & - \\
\hline & SG13 & $>0.15$ & - & - & - & - \\
\hline & SG20 & $>0.40$ & - & - & - & - \\
\hline & SG24 & 0.13 & 0.2 & $\mathrm{X}$ & $\mathrm{X}$ & $>0.20$ \\
\hline & SG25 & $>0.14$ & - & - & - & - \\
\hline & SG34 & $>0.35$ & - & - & - & - \\
\hline & SG43 & 0.42 & $>0.52$ & - & - & - \\
\hline & SG44 & 0.4 & $\mathrm{X}$ & 0.7 & $>0.70$ & - \\
\hline & SG45 & 0.4 & 0.46 & $\mathrm{X}$ & $\mathrm{X}$ & $>0.50$ \\
\hline & SG46 & 0.2 & $\mathrm{X}$ & $\mathrm{X}$ & $>0.51$ & - \\
\hline & SG70 & 0.05 & $\mathrm{X}$ & $\mathrm{X}$ & 1.3 & $>1.30$ \\
\hline & SG74 & 0.05 & $>0.12$ & - & - & - \\
\hline & SG81 & 0.32 & 0.42 & $>0.51$ & - & - \\
\hline & SG86 & 0.45 & 0.95 & $>1.15$ & - & - \\
\hline & SG87 & 0.31 & 0.65 & 1.06 & $\bar{X}$ & $>1.15$ \\
\hline & SG88 & $\mathrm{X}$ & $\mathrm{X}$ & 0.48 & 1.1 & $>1.52$ \\
\hline \multirow{10}{*}{$\begin{array}{l}\text { Grey Sandy } \\
\text { Colluvium }\end{array}$} & SG09 & 0.09 & 0.36 & $\mathrm{X}$ & $>0.47$ & - \\
\hline & SG10 & 0.05 & $>0.10$ & - & - & - \\
\hline & SG12b & 1.15 & $\mathrm{X}$ & $>1.30$ & - & - \\
\hline & SG16 & 0.28 & 0.4 & 0.4 & $>0.47$ & - \\
\hline & SG17 & 0.15 & $>0.30$ & - & - & - \\
\hline & SG25 & $>0.14$ & - & - & - & - \\
\hline & SG30 & 0.05 & $\bar{X}$ & $\mathrm{X}$ & $\mathrm{X}$ & $>1.50$ \\
\hline & SG31 & $>0.05$ & - & - & - & - \\
\hline & SG69 & 0.31 & 0.36 & $X$ & $>0.46$ & - \\
\hline & SG74 & 0.05 & $>0.12$ & - & - & - \\
\hline
\end{tabular}




\begin{tabular}{|c|c|c|c|c|c|c|}
\hline & SG83 & 0.3 & $\mathrm{X}$ & $\mathrm{X}$ & 0.5 & $>0.65$ \\
\hline \multirow{7}{*}{$\begin{array}{l}\text { Grey Clayey } \\
\text { Colluvium }\end{array}$} & SG32 & $>0.05$ & - & - & - & - \\
\hline & SG33 & 0.1 & $\mathrm{X}$ & $>0.20$ & - & - \\
\hline & SG56 & $>0.31$ & - & - & - & - \\
\hline & SG59 & 0.43 & $>0.50$ & - & - & - \\
\hline & SG60 & 0.12 & $\bar{X}$ & $>0.90$ & - & - \\
\hline & SG82 & 0.94 & $\bar{X}$ & $>1.43$ & - & - \\
\hline & SG89 & $\mathrm{X}$ & 0.17 & $\mathrm{X}$ & $\mathrm{X}$ & $>0.50$ \\
\hline \multirow{5}{*}{$\begin{array}{c}4 \\
\text { Ferruginized } \\
\text { Profiles }\end{array}$} & SG05 & 0.2 & $\mathrm{X}$ & $0.51^{* *}$ & 0.67 & $>0.96$ \\
\hline & SG07 & 0.08 & $>0.21 * *$ & - & - & - \\
\hline & SG11 & 0.3 & $0.50^{* *}$ & $>0.60^{* *}$ & - & - \\
\hline & SG23 & 0.52 & $0.70 ?$ & - & - & - \\
\hline & SG28 & $0.43^{*}$ & $>0.65$ & - & - & - \\
\hline \multirow{10}{*}{$\begin{array}{c}5 \\
\text { Duplex Soils }\end{array}$} & SG01 & 0.15 & 0.5 & 0.7 & $>0.90$ & - \\
\hline & SG02 & $>0.05$ & - & - & - & - \\
\hline & SG04 & $>0.45$ & - & - & - & - \\
\hline & SG47 & $>0.32$ & - & - & - & - \\
\hline & SG48 & $>0.05$ & - & - & - & - \\
\hline & SG49 & $>0.39$ & - & - & - & - \\
\hline & SG50 & $>0.05$ & - & - & - & - \\
\hline & SG51 & $>0.21$ & - & - & - & - \\
\hline & SG55 & $>0.05$ & - & - & - & - \\
\hline & \multicolumn{3}{|c|}{ SG61, SG64, SG72, SG77, SG78 } & \multicolumn{3}{|c|}{ Surface description only } \\
\hline
\end{tabular}

- $\quad-\quad$ Hole terminated prior to possible occurrence of horizon

- X Horizon distinctly absent

- $>$ Final depth represents end of profile due to hand auger refusal or other reasons

- ? Underlying material contradicting anticipated sequence

- $\quad$ ** $\quad$ Extensive ferruginization;

- $\quad$ slight ferruginization 
- Completely Weathered Granite - slightly moist, (yellow or light) brown/ light whitish grey, silty sandy GRAVEL with angular, fine to medium feldspar and quartz gravel

- Highly Weathered Granite - slightly moist, light brown speckled white and orange, silty SAND or sandy SILT with quartz and feldspar gravel.

Type 2: grey sandy colluvium $(n=11)$. The exception here is SG12b where colluvium is $1.15 \mathrm{~m}$ in thickness, changing colour from grey to greenish grey, and underlain by calcrete developed in leached residual granite. No laboratory analyses are available for this material. The typical material succession is as follows:

- Colluvium - slightly moist, (light or brownish) grey, (voided; open; pinholed), silty gravelly SAND or (clayey or gravelly) silty SAND; occasionally with mixed gravel

- Pebble Marker - slightly moist, light grey, silty SAND with abundant fine to medium, subangular quartz and feldspar gravel or granite gravel

- Residual Granite (occasionally reworked) - slightly moist, (yellowish) brown, (gravelly) silty SAND with abundant, fine to medium, subangular quartz and feldspar gravel

- Completely Weathered Granite - slightly moist, light brown/ white speckled grey and orange, silty sandy GRAVEL (gravel occasionally ferruginized)

- Highly Weathered Granite - slightly moist, light brown speckled white and orange, silty SAND or sandy SILT with quartz and feldspar gravel.

Type 3: grey clayey colluvium $(n=7)$. The exception here is SG60 where colluvium grades into calcified residual granite. With the obvious exception of the more gravelly pebble marker, surface soils are generally clay-silt SAND becoming gravelly SAND with depth. Clays easily reach $20 \%$ by mass and up to $40 \%$ in surface horizons when 
considering all cohesive particle sizes (clay and silt) together. Soils generally exhibit very high plasticity with plasticity indices ranging between 15\% (pebble marker) and 25\% (colluvium). All soils are classified as SC (clayey sand) according to USCS. The typical material succession is as follows:

- Colluvium - dry to slightly moist, dark (brownish) grey (speckled orange), (pinholed), (very stiff), silty sandy CLAY/ clayey SAND

- Pebble Marker - slightly moist, black, clayey gravelly SAND with abundant quartz cobbles and pebbles

- Residual Granite - moist, dark grey speckled orange, clayey gravelly SAND

- Highly Weathered Granite - slightly moist, (dark or orange) brown, silty gravelly SAND becoming silty to sandy GRAVEL

Type 4: ferruginized soils $(n=5)$. These profiles showed ferruginization, notably of the pebble marker and residual granite. No laboratory analyses are available for this material. Profile SG23 does not completely comply with the typical succession as a sand lens in which ferruginization is evident underlies the pebble marker. The typical material succession is as follows:

- Colluvium - dry to moist, pale or light brown (mottled orange)/ light grey, (loose), (voided and pinholed), (gravelly) silty SAND

- Pebble Marker - dry, light brown, silty SAND with abundant fine to medium, subangular quartz and feldspar gravel; matrix-supported (with abundant Fe and Mn nodules)

- Residual Granite - moist, yellowish white speckled orange, loose, open, silty gravelly SAND with scattered Fe and Mn nodules and fine quartz gravel; ferruginized

- Completely Weathered Granite - wet, brown speckled orange blotched black, loose, clayey silty gravelly SAND 
- Highly Weathered Granite - wet, light olive brown mottled orange, loose, silty gravelly SAND with Fe and Mn nodules.

Type 5: duplex soils $(n=10)$. The sodic duplex soils are generally characterised by dark grey to black surface soils of distinct clayey texture. The deeper in-situ (not transported) soils resemble typical granitic soils, being white to reddish brown in colour and mainly of sandy texture. Due to the dry state of the clayey soils during investigation, excavation was difficult in stiff to very stiff clays and exposed profiles are, therefore, generally shallow. Only one profile was sampled to represent duplex profiles (SG01). Clay content varies between $8 \%$ and $26 \%$ with recorded plasticity indices between moderate $11 \%$ (colluvium) and very high $22 \%$ (pebble marker). Regardless, sand still makes up the bulk of all horizons, accounting for more than $50 \%$ by mass of all samples analysed. All soils are classified as SC according to the USCS. 15 such profiles were noted of which 10 were profiled as follows:

- Topsoil - dry to slightly moist, light grey, silty gravelly SAND with scattered fine gravel, leached topsoil

- Colluvium - slightly moist pale grey speckled orange/ dark (brownish) grey, (very stiff), (shattered; slickensided; voided), (silty) clayey SAND

- Pebble Marker - slightly moist, dark grey becoming black, (shattered; desiccated; voided), clayey gravelly SAND with gravel

- Residual Granite - slightly moist, grey, silty gravelly SAND; reworked

- Completely Weathered Granite - slightly moist, light brown, silty gravelly SAND with scattered gravel

Type 6: alluvium. Alluvial profiles vary slightly based on stream order. For this sake, distinction is made between Type 6-1 first order, 6-2 second order and 6-3 third order alluvium. First order streams generally form through seepage from sodic sites (profile 
5: duplex soils) and are characterised by slightly moist, dark grey speckled orange becoming orange brown speckled white, silty gravelly SAND (e.g. SG84). Second order streams are characterised by bedrock at shallow depth, commonly outcropping in stream channels. Side banks generally comprise slightly moist becoming moist, grey to white-orange, medium dense, often desiccated at surface, (silty) clayey SAND. Granite or amphibolite underlies these materials at shallow depths (e.g. SG57, SG57B, SG58). Third order valley floors are wide with unconsolidated sandy alluvium described as slightly moist, light brown, very loose becoming medium dense, slightly pinholed, slightly gravelly slightly silty SAND (e.g. SG06, SG71, SG79). The confluence of second and third order streams is influenced by the materials from second order streams which are commonly more clayey than in the third order streams (e.g. SG58). Surface materials here comprise slightly moist, dark grey becoming orange brown, medium dense to dense, open, clayey silty SAND underlain by more gravelly sandy materials at depth. No laboratory analyses are available for this material.

Additional data from outside of KNP and covering the Nelspruit Suite in the Kiepersol, White River and Bushbuckridge areas are summarised in the Appendix. Interestingly, potentially due to the proximity to the escarpment and somewhat higher annual precipitation, the soils in these areas are more clayey and more plastic than those encountered in the KNP.

\subsection{Geomorphology and Landforms}

Local variations exist, but typical material successions for basement granites in temperate regions north-eastern South Africa (broadly labelled, within context, as humid and arid) are shown in Figure 11. The more humid areas (such as JDG and E-L portion of G-HRG) exhibit deeper weathering profiles associated with distinct 


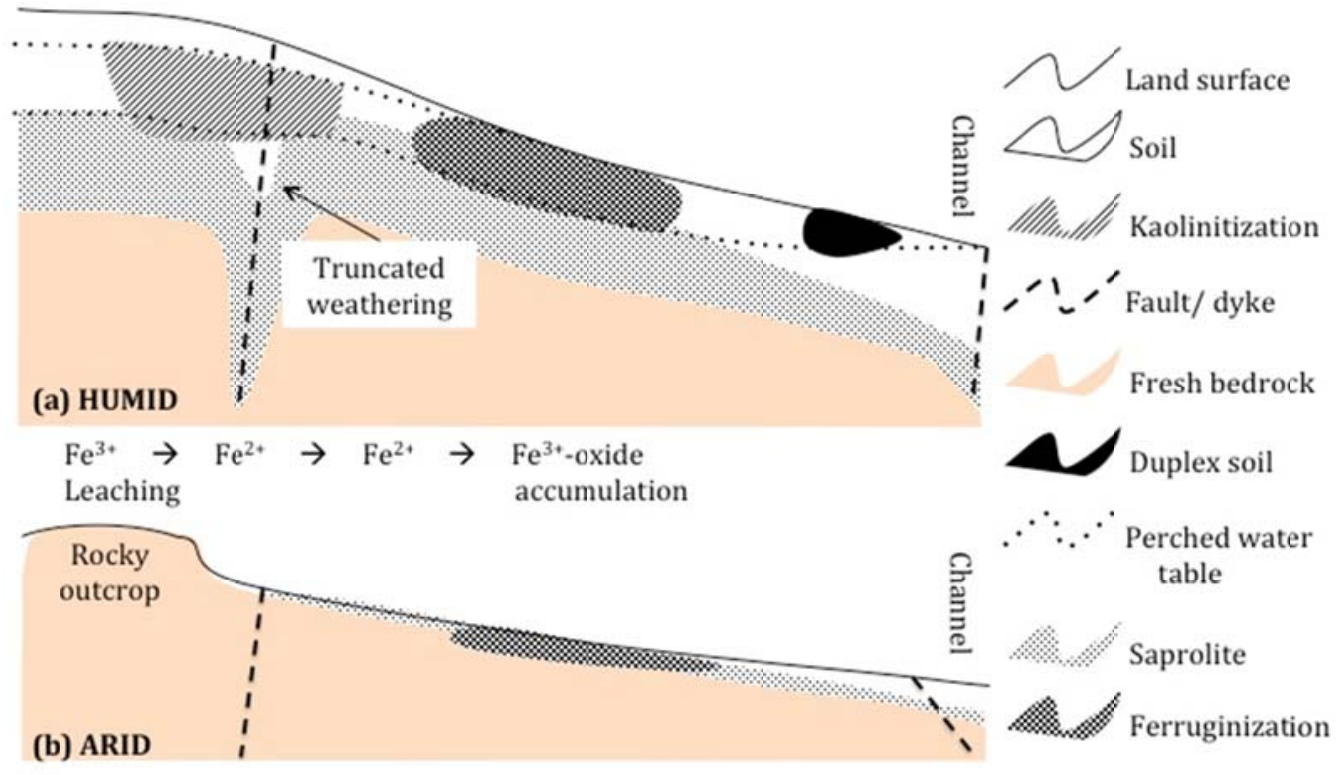

Figure 11. Typical material successions and pedogenetic processes from a hillcrest (left) to drainage channel (right) underlain by basement granite in humid and arid settings.

kaolinitization on the upper slopes (likely due to chemical decomposition of feldspars), ferruginization on midslopes to lower slopes and often the formation of duplex soils on footslopes. More arid regions, however, lack the deep soil profiles and ferruginization is more common on or near surface with typical barren outcrops forming hillcrests.

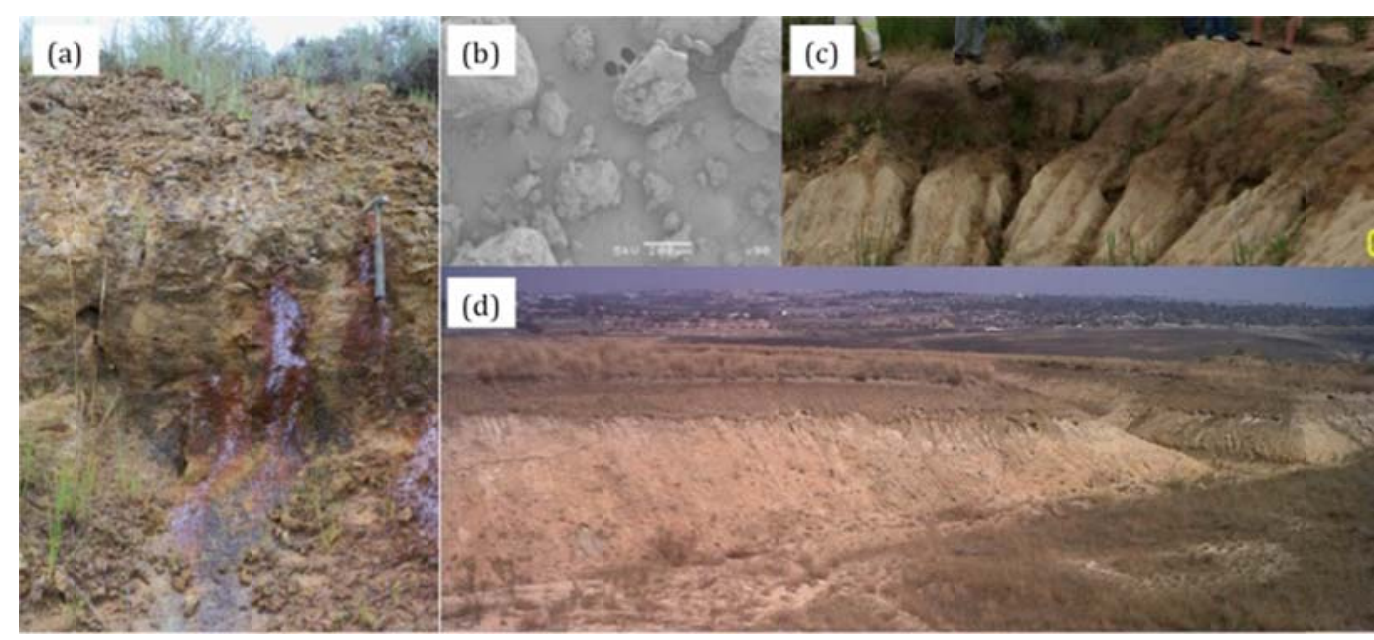

Figure 12. (a) Seepage from ferricrete on the midslope; (b) kaolinite covering quartz (1 500 $\mu \mathrm{m}$ across); (c) dispersive/ erodible behaviour; and (d) view of excavation in Lanseria Gneiss. 


\subsubsection{Lanseria Gneiss}

Figure 12 shows a photographic exposé of an excavated hillslope wetland underlain by Lanseria Gneiss.

The geomorphological development of the Midrand area (between Johannesburg and Pretoria) resulted in three distinct soil profiles (McKnight 1999):

- Above 1600 mamsl, transported and residual soils are typically thick, collapsible, very kaolinitic and with deep bedrock.

- Between 1500 and 1600 mamsl, corestones and variable weathering troughs are evident on the exposed land surface.

- Remnants of the ferricrete cap of the old African land surface are exposed in certain areas of the East Rand and differential weathering is present adjacent to intruded dykes.

The Lanseria Gneiss forms typical weathering profiles with variable bedrock topography and characteristic positions of kaolinitization (kaolinite-enrichment) and ferruginization (iron-enrichment) associated with a truncated weathering profile on the upper slope and perched water tables forming on midslopes. Intrusive dykes, melanogneiss bands or faults typically occur at drainage features and near hillcrests, forming the characteristic truncated weathering in the latter. Given the low permeability of granite bedrock, perched water tables typically form overlying bedrock, resulting in the translocation of kaolinite and the formation of ferricrete. Wetland-conditions are common overlying the ferruginized areas, often with the honeycomb ferricrete serving as the horizon in which interflow occurs (Figure 12a). Given the plagic composition of the trondhjemite, the soils are somewhat dispersive in places. 
Figure 13 shows a photographic exposé of the E-L and W-L study areas underlain by GHRG.

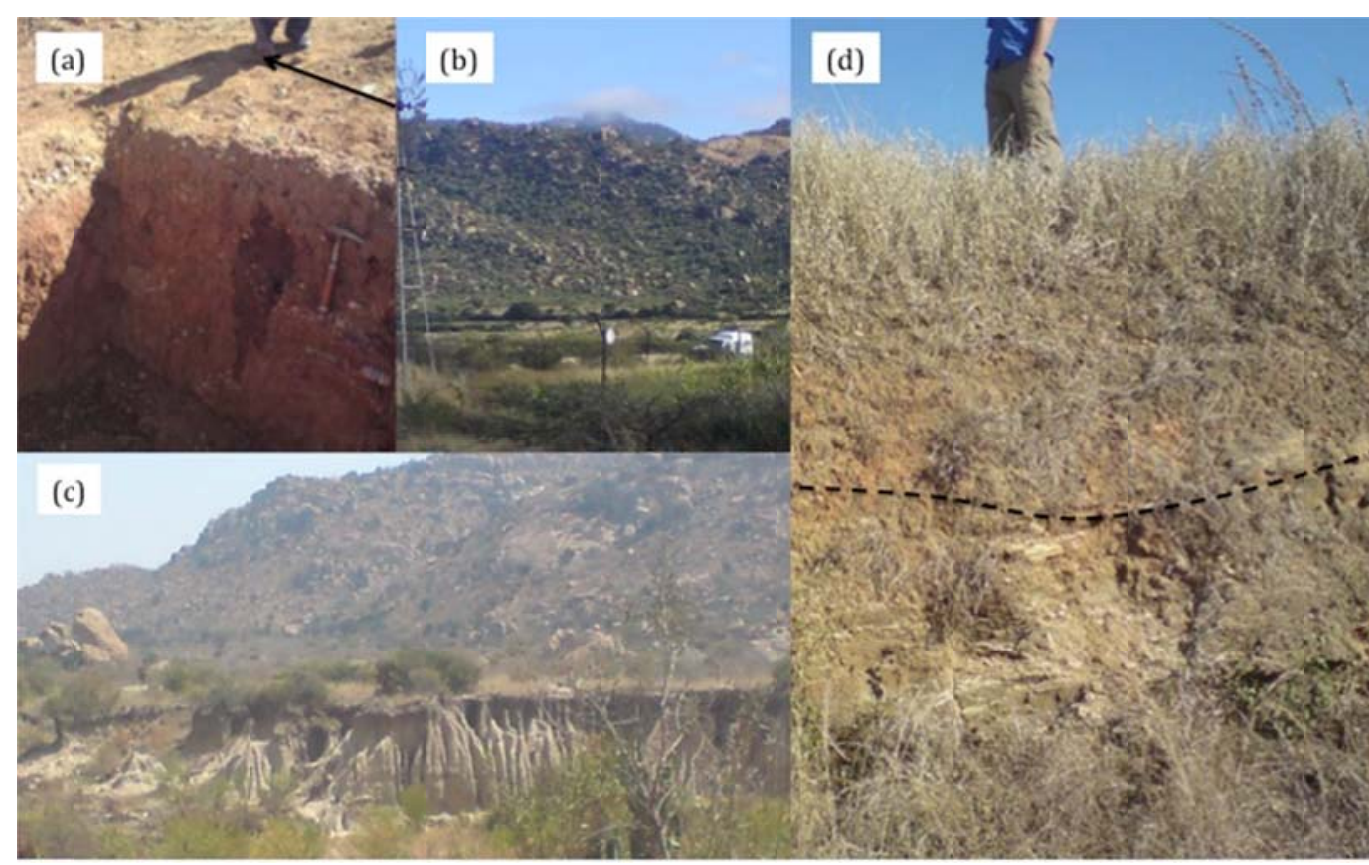

Figure 13. (a) Lateral seepage due to preferential flow from a percolation test conducted 400 mm below surface at the arrow in E-L; (b) rocky outcrop in W-L; (c) dispersive/ erodible behaviour in W-L; and (d) soil underlain by weathered bedrock (E-L).

Preferential flow is commonly associated with the well-leached upper soil horizons (Figure 13a) and is often exacerbated by insect or animal burrows, plant roots and historical land use practices such as encountered in ploughed land. This can also be ascribed to the high feldspar content resulting in kaolinitic clays forming and materials being subject to erosion or dispersive behaviour (Figure 13c).

In the more humid areas (e.g. study area E-L), the profiles resemble those in Figure 11, although ferruginization may be less evident and, although soils show mottling and discolouration, hardpan ferricrete is less common. The more arid regions, however, 
exhibit near-outcrop conditions on the crests and slopes with ferruginization near surface on the midslopes.

\subsubsection{Nelspruit Suite}

Figure 14 shows a photographic exposé of the Nelspruit Suite in the SGRS, KNP.

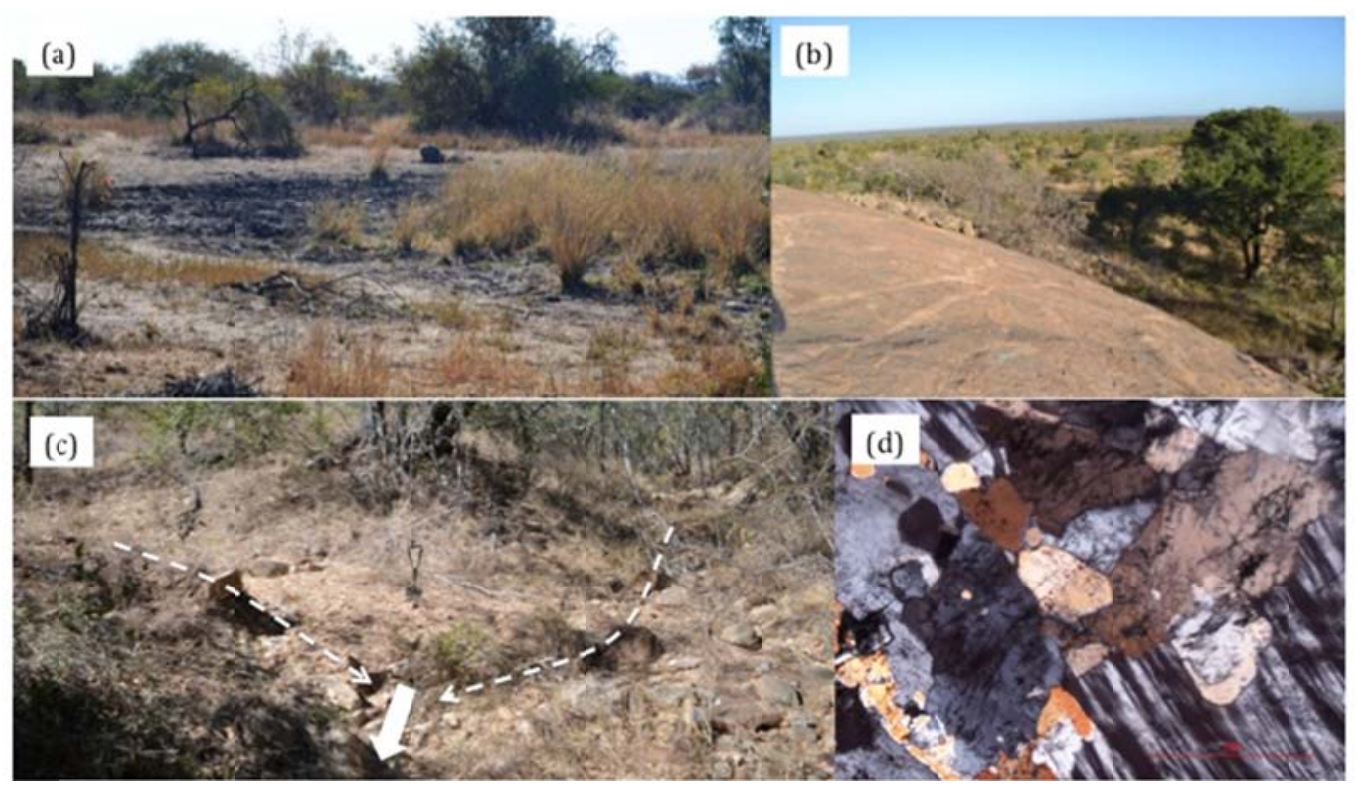

Figure 14. (a) Typical duplex soils on footslopes; (b) view from Matekenyane inselberg; (c) confluence of two first order channels to form a second order; (d) polarised-light thin section of fresh granite ( $3 \mathrm{~mm}$ across) of the Nelspruit Suite in the SGRS, KNP.

The area now outlined as the SGRS falls within the Renosterkoppies Land Type of the Skukuza Land System and has hillslopes with or without footslopes, depending on the ability or inability of the drainage features to incise their drainage channels. Large seasonal (third and fourth order) and small seasonal (first and second order; Figure 14b) drainage channels are present with the latter lacking a prominent footslope. The third and fourth order drainage features subsequently influence relief more with the site sloping towards these features. Leaching appears to have a greater effect on midslopes than on hillcrests, creating so-called sodic sites (Figure 14a) at the transition area from 
the hillcrest to the midslope or on the midslope in the event of first order drainage features (Venter 1986).

The granite landscape is characterised by gently to moderating undulating topography with scattered inselbergs (Figure 14b), often in clusters, forming due to locally higher resistance against weathering (Venter and Bristow 1986).

A summary of more than 80 data points described for the SGRS provide three typical profile successions towards various drainage channels Figure 15. The numbers indicate typical engineering geological material descriptions as detailed in the preceding paragraph.

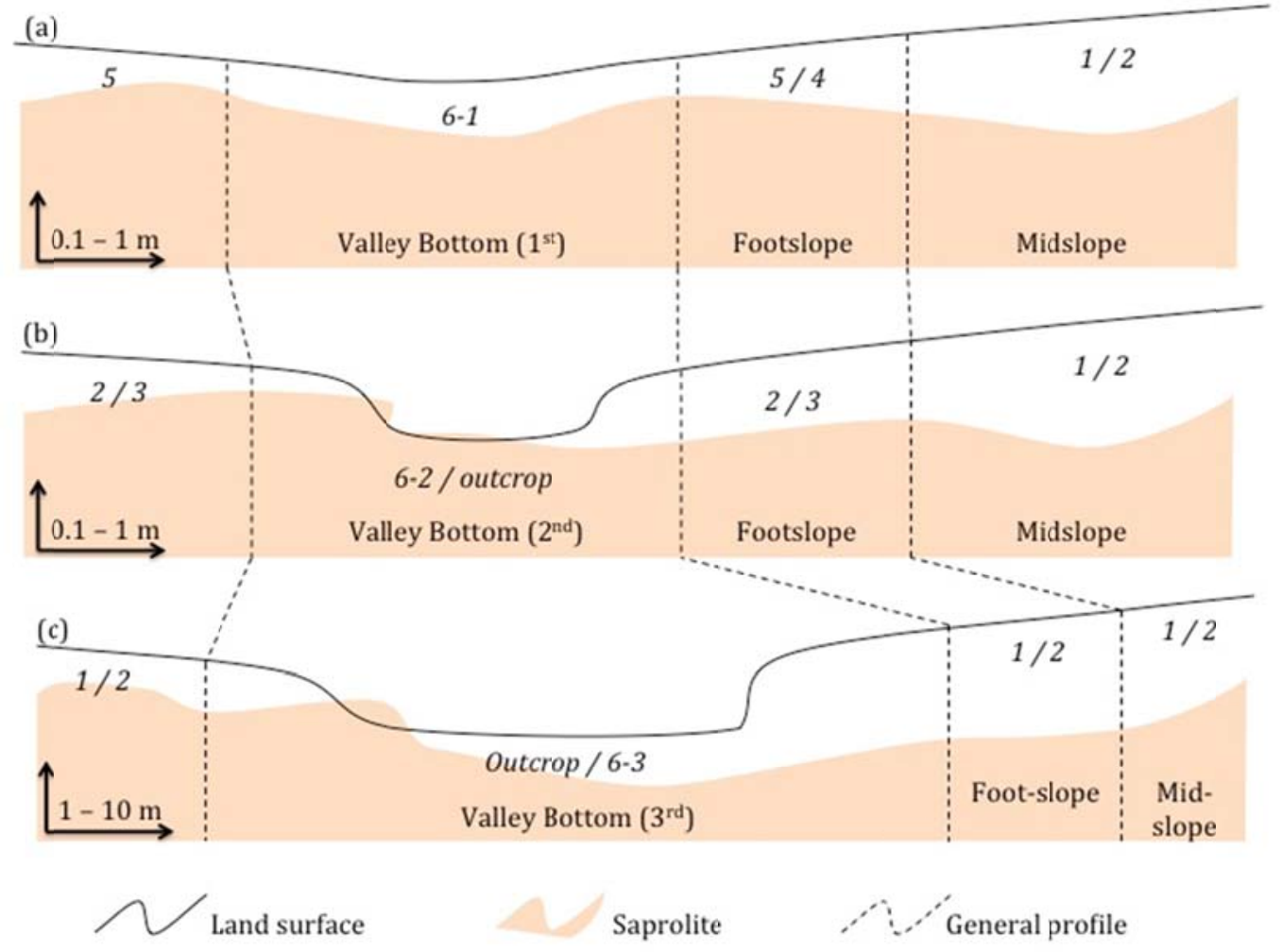

Figure 15. Typical material successions and landforms approaching (a) first order, (b) second order and (c) third order drainage channels in the SGRS, KNP. 


\subsection{Hydrostratigraphy}

\subsubsection{Lanseria Gneiss}

Groundwater is not commonly used for large-scale abstraction in the Gauteng area. Johannesburg is mainly supplied by the Vaal River and Rand Water Board, with Pretoria being supplied extensively by the Rand Water Board and springs in the Chuniespoort Group dolomite to the north of the Lanseria Gneiss (DWAF 2002; Dippenaar 2013). The Lanseria Gneiss, therefore, is mostly used as a rural supply or for local irrigation.

Groundwater is generally deeper than $10 \mathrm{~m}$ and a thick soil and fractured intermediate zone exists. Limited (14) field percolation tests yield vertical saturated hydraulic conductivities ranging between $2.60 \times 10^{-4} \mathrm{~m} / \mathrm{s}$ and $1.5 \times 10^{-5} \mathrm{~m} / \mathrm{s}$.

\subsubsection{Goudplaats-Hout River Gneiss (G-HRG)}

A study characterising a large volume light non-aqueous phase liquid (LNAPL) spill found gneisses in the central and western portions of the G-HRG Suite to have preferential flow directions associated with the dip direction of the gneissosity, as well as to be influenced by significant geological structures such as faults and intrusions such as diabase dykes (Dippenaar et al. 2005).

Further work in other areas of the same lithology evaluated the most important influences on anticipated borehole yield and found that certain structural and intrusive features distinctly promote or reduce transmissivity. Based on location (eastern and western parts of the Limpopo Province), present-day climate (arid versus humid) and directions of major structural features, more than 1000 constant discharge and more 
than 1000 step-drawdown tests were analysed and superimposed on climatic, geomorphological and tectonic settings. The findings can be summarised as shown in Table 3 where "high" represents $\mathrm{T}>100 \mathrm{~m}^{2} / \mathrm{d}$, "moderate" $\mathrm{T}>10 \mathrm{~m}^{2} / \mathrm{d}$ and "low" below (Dippenaar et al. 2009).

The vadose zone also typically comprises a soil zone and a fractured intermediate zone. Field percolation and double ring infiltration tests yield vertical saturated conductivities of $1.4 \times 10^{-3} \mathrm{~m} / \mathrm{s}$ to $5.00 \times 10^{-5} \mathrm{~m} / \mathrm{s}$ (Dippenaar et al. 2010).

\subsubsection{Nelspruit Suite}

The groundwater type associated with the Nelspruit Suite is predominantly $\mathrm{Na}-\mathrm{HCO}_{3}$ and was discussed for the entire KNP by Leyland and Witthüser (2008) based on data from the National Groundwater Archive (NGA) maintained by the Department of Water Affairs (DWA). The authors ascribe this as the assumed long-term equilibrium between groundwater chemistry and underlying acidic igneous lithology.

No field percolation or infiltration tests were conducted for the Nelspruit Suite and nou groundwater data are included in this review.

\section{Findings}

\subsection{Weathering profiles}

Basement granites in South Africa vary based on mineralogy, igneous or metamorphic textures and younger structural influences. This, together with climatic variations, result in distinct geomorphology and landforms with characteristic soil successions both 
Table 3. Relative expected yields for different climatic and neotectonic settings in the Goudplaats-Hout River Gneiss Suite ranked as "high", "moderate" or "low" for the Hout River Shear Zone (HRSZ), open structures parallel to major fault strike, closed structures perpendicular thereto, and contacts with younger granite plutons (Dippenaar et al. 2009).

\begin{tabular}{|c|c|c|c|c|}
\hline Locality & $\begin{array}{c}\text { Western Limpopo } \\
\text { (W-L) }\end{array}$ & $\begin{array}{c}\text { Western Limpopo } \\
\text { (W-L) }\end{array}$ & $\begin{array}{c}\text { Eastern Limpopo } \\
\text { (E-L) }\end{array}$ & Eastern Limpopo \\
& Arid & Humid & Arid & Humid \\
\hline Climate & ENE-WSW & NE-SW & ENE-WSW & NE-SW \\
\hline Major fault strike & High & High & High & Moderate \\
\hline HRSZ & Low & Moderate & Low & Moderate \\
\hline Open structure & Moderate & Moderate & High & Low \\
\hline Closed structure & Low & High & Moderate & \\
\hline
\end{tabular}


vertically and between crests and drainage channels. Variable bedrock topography is associated with most such granitic terrains in temperate to humid areas in South Africa and ferricrete or duplex soils are commonly found on midslopes to footslopes.

Ferruginization is common, notably in the Lanseria Gneiss (JDG) and to a lesser extent in the Goudplaats-Hout River Gneiss Suite (G-HRG). Perched water tables form overlying bedrock and result in ferricrete which serve as a zone of interflow when nodular to honeycomb, and which becomes an aquitard when in the hardpan stages of formation. Ferricrete occurs to a lesser extent in the Nelspruit Suite and the translocation of clay minerals is more common, forming so-called duplex soils. These duplex soils also sometimes exist on the footslopes in the JDG.

Most of these granite profiles are characterised by some degree of translocation of clay minerals, mostly comprising kaolinite. This often results in collapsible surface horizons, which may also be dispersive when the granite contains significant amounts of albite.

Bedrock depths vary, notably based on climate (which influences the depth of chemical weathering) and landform.

\subsection{Engineering geology}

Bulk of the residual and weathered granites depicts - as anticipated - low plasticity and low potential expansiveness. Kaolinite, although often present in abundance, remain inactive. Active clays may, however, be present in the duplex soils where these transported materials often form zones of low water infiltration and high water retention. 
Apart from collapsible soil fabric and possible dispersive behaviour, the main identified geotechnical constraints are shallow bedrock, granite boulders or hardpan ferricrete which affect excavatability. Additionally, seepage lines, hillslope wetlands and seepage problems have to be anticipated given the low permeability of bedrock and the altered hydrology of the profile resulting from leaching and translocation.

\subsection{Surface and phreatic hydrology}

Groundwater occurrence is mainly governed by significant structures such as shear zones and faults, as well as contacts with younger granitic plutons. The influence of the orientations of these structures determines whether they are open for the transmission of water and also commonly govern the directions of major drainage features.

The South African basement granites discussed in this paper comply with the general definition of a catena and more often than not form pedocretes or duplex soils. This results in yet further interflow and commonly this water forms seepage lines or ephemeral wetlands on the midslopes and lower slopes. These are typically dry, but contribute to the flow in higher order streams. These wetlands, however, do not always fall within the classical definition of a wetland, requiring areas that are periodically or

permanently saturated and sustains growth of plants requiring waterlogged conditions (e.g. NWA 1998).

\subsection{Vadose zone hydrology}

In both the G-HRG and JDG, saturated vertical hydraulic conductivities of surface materials are typically between $1 \times 10^{-4}$ and $1 \times 10^{-5} \mathrm{~m} / \mathrm{s}$ with local anomalous values due to preferential flow, fractured rock, or other influences. 
Interflow is almost always of notable importance on the granite terrains. Low permeability bedrock, coupled with ferruginization and clay translocation result in water in the unsaturated zone being forced downslope, often to daylight in the form of seepage lines or ephemeral hillslope wetlands. The connection with the regional groundwater table is, therefore, not always direct and recharge may only occur in very specific recharge zones such as drainage channels.

In assessing vadose zone conditions, the need for a multi-disciplinary effort is clear. In understanding the basics of the science, at least soil science, geology and proper understanding of the hydrological cycle and all associated disciplines are required as per the proposed triangle of vadose zone hydrology. To compile, understand and interpret the vadose zone model for any application, more detail is required on the soil zone, intermediate zone and the capillary fringe, as well as any associated processes of infiltration, percolation, recharge, interflow, throughflow or evapotranspiration from the subsurface (Figure 16).
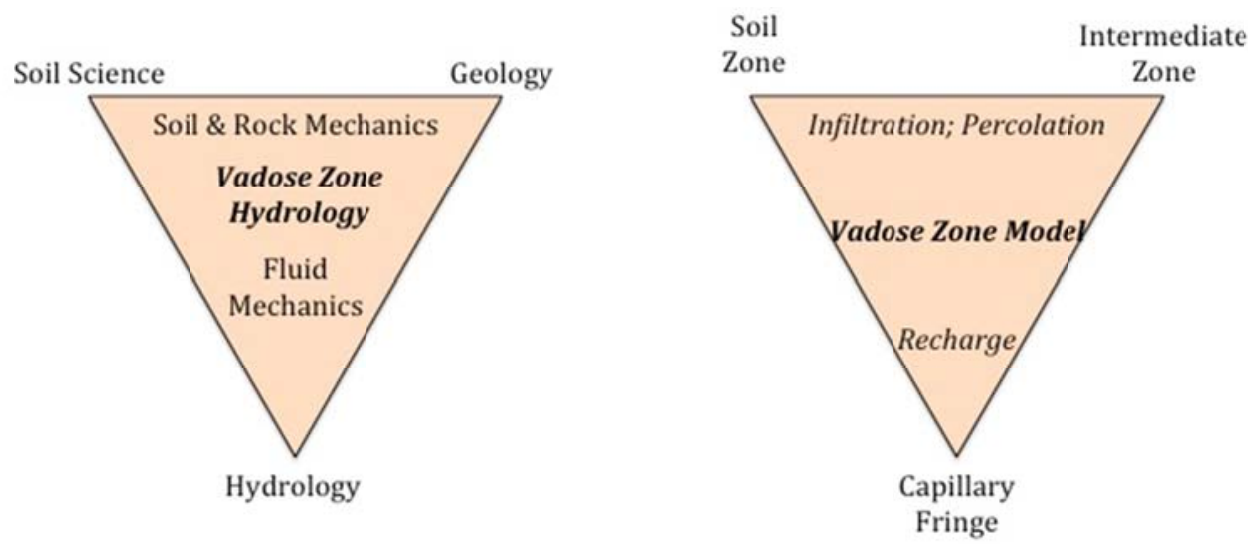

Figure 16. Triangle of vadose zone hydrology and of compilation of the vadose zone model. 


\section{Acknowledgements}

The author wishes to acknowledge the Water Research Commission of South Africa (WRC) for funding of project K5/2052 on Multidisciplinary Vadose Zone Hydrology, as well as previous WRC projects paving the road to this review, including a detailed project on Basement Aquifers (Witthüser et al. 2010) and a project focussed around the Preliminary Vadose Zone Classification Methodology for two selected basement catchments (Dippenaar et al. 2010). The Johannesburg Dome was additionally addressed during literature review for a WRC project on the groundwater resources of Pretoria. Additional data from geotechnical site investigations in both Limpopo and Gauteng Provinces were obtained from the private database of both authors. A final word of thanks is extended to South African National Parks (SANParks) for the inclusion of regional geological mapping data from the Skukuza region for which they kindly allowed access to the Kruger National Park (KNP).

Thanks are also extended to the journal, its editors and reviewers for considering this submission and for valuable feedback.

\section{Bibliography}

Adams, S. (2009). Basement aquifers of southern Africa: overview and research needs. In: Titus, R., Beekman, H., Adams, S. and Strachan, L. (Eds.). (2009). The basement aquifers of South Africa. WRC Report No. TT 428/09. Water Research Commission. Pretoria. Pp1-4.

Alem, A., Elkawafi, A., Ahfir, N-D. and Wang, HQ. (2013). Filtration of kaolinite particles in a saturated porous medium: hydrodynamic effects. Hydrogeology Journal. 21(3):573-586. 
Allen, D. M., Schuurman, N., Deshpande, A. and Scibek, J. (2007). Data integration and standardization in cross-border hydrogeological studies: a novel approach to hydrostratigraphic model development. Environmental Geology. 53:1441-1453. Angelone, M., Cremisini, C., Piscopo, V., Proposito, M. and Spaziani, F. (2009). Influence of hydrostratigraphy and structural setting on the arsenic occurrence in groundwater of the Cimino-Vico volcanic area (central Italy). Hydrogeology Journal. 17:901-914.

Arcworth, R. I. (1987). The development of crystalline basement aquifers in a tropical environment. Quarterly Journal of Engineering Geology 20:265-272. Barton. J. M. (Jr.), Bristow, J. W. and Venter, F. J. (1986). A summary of the Precambrian granitoid rocks of the Kruger National Park. Koedoe. 29:39-44. Bock, H. (2006). Common ground in engineering geology, soil mechanics and rock mechanics: past, present and future. Bull Eng Geol Environ. 65:209-216.

Botha, F. S. and van Rooy, J. L. (2001). Affordable water resource development in the Northern Province, South Africa. Journal of African Earth Sciences. 33:687-692.

Brady, N. C. \& Weil, R. R. (1999). The nature and properties of soils. 12th Ed. Prentice Hall. USA. ISBN 0-13-852444-0.

Brink, A. B. A. (1981). Engineering geology of southern Africa: volume 2. Building Publications. South Africa. Pp.17-28.

Brink, A. B. A. and Bruin, R. M. H. (2001). Guidelines for soil and rock logging in S. A. Association of Engineering Geologists - South African Section (AEG-SA Section)/ South African Institution of Civil Engineering -Geotechnical Division (SAICE)/ South African Institute for Engineering and Environmental Geologists (SAIEG). Pretoria. Ceryan, S., Tudes, S. and Ceryan, N. (2008). Influence of weathering on the engineering properties of Harsit granitic rocks (NE Turkey). Bull Eng Geol Environ. 67:97-104. 
Cullum, C. and Rogers, K. (2011). A framework for the classification of drainage networks in savanna landscapes. WRC Report No. TT 498/11. Water Research Commission. Pretoria.

Dewandel, B., Lachassagne, P., Wyns, R., Maréchal, J. C. and Krishnamurty, N. S. (2006). A generalized 3-D geological and hydrogeological conceptual model of granite aquifers controlled by single or multiphase weathering. Journal of Hydrology. 330:206-284.

Dippenaar, M. A., Sole, M. D., van Rooy, J. L., du Toit, G. J. and Reyneke, J. L. (2005). Determining actual LNAPL plume thickness: review and case study in a fractured aquifer. Bull Eng Geol Environ. 64:347-360.

Dippenaar, M., Van Rooy, L. and Croucamp, L. (2006). The use of index laboratory testing to determine the engineering behaviour of granitic saprolite. Proceedings: International Association of Engineering and Environmental Geologists IAEG. Nottingham, UK.

Dippenaar, M. A., van Rooy, J. L., and Witthüser, K. T. (2009). Groundwater occurrence in basement aquifers in Limpopo Province, South Africa: model-settingscenario approach. Environmental Earth Science. 59:459-464.

Dippenaar, M. A., Van Rooy, J. L., Moyo, A., Freëse, R. and Makonto, O. T. (2010). Preliminary vadose zone classification methodology (Molototsi and Middle Letaba quaternary catchments). WRC Report No. KV 243/10. Water Research Commission. Pretoria.

Dippenaar, M. A. (2013). Hydrogeological Heritage Overview: Pretoria's fountains arteries of life. WRC Report No. SP 44/13. Water Research Commission. Pretoria. DWAF [Department of Water Affairs and Forestry]. 2002. Water resources situation assessment study: Crocodile West and Marico Water Management Area. Volume 1. DWAF Report No. P01000/00/0301. Pretoria. 
Foster, S. (1984). African groundwater development: the challenges for hydrological science. IAHS Publication 334. Wallingford UK. Pp.3-12.

Foster, S. (2012). Hard-rock aquifers in tropical regions: using science to inform development and management policy. Hydrogeology Journal. 20(4):659-672. Foster, S. (2012). Hard-rock aquifers in tropical regions: using science to inform development and management policy. Hydrogeology Journal. 20(4):659-672. Heinz, J. and Aigner, T. (2003). Hierarchical dynamic stratigraphy in various Quaternary gravel deposits, Rhine glacier area (SW Germany): implications for hydrostratigraphy. Int. J. Earth. Sci. (Geol. Rundsch.). 92:923-938.

Holland, M and Witthüser, K. T. (2011). Evaluation of geologic and geomorphologic influences on borehole productivity in crystalline bedrock aquifers of Limpopo Province, South Africa. Hydrogeology Journal. 19:1065-1083.

Jenn, F., Nagare, R., Porzig, M. and Voigt, H.-J. (2007). Chapter 5.2.7.1. Infiltrometer and Permeater Tests. In: Knödel, K., Lange, G. and Voigt, H.-J. (eds.) Environmental geology: handbook of field methods and case studies. Springer. Heidelberg. pp.649680.

Jennings, J. E., Brink, A. B. A. and Williams, A. A. B. (1973). Revised guide to soil profiling for civil engineering purposes in South Africa. Die Siviele Ingenieur in SuidAfrika/ The Civil Engineer in South Africa. 15:1.

Jones, M. J. (1985). The weathering zone aquifers of the Basement Complex areas of Africa. Quarterly Journal Of Engineering Geology 18:35-46.

Keary, P. (2001). The New Penguin Dictionary of Geology. 2nd Ed. Penguin Books. England

Key R. M. (1992). An introduction to the crystalline basement of Africa. In: Wright, E.P. and Burgess, W.G. (eds.). Hydrogeology of Crystalline Basement Aquifers in Africa. Geological Society Special Publication No 66. Geological Society. London. 
King, L. C. (1975). Geomorphology: a basic study for civil engineers. Proceedings of the Sixth Regional Conference for Africa on Soil Mechanics and Foundation Engineering. Durban. 2:259-263.

Kirschbaum, A., Martínez, E., Pettinari, G. and Herrero, S. (2005). Weathering profiles in granites, Sierra Norte (Córboda, Argentina). Journal of South American Earth Sciences. 19:479-493.

Koita, M., Jourde, H., Koffi, K. J. P., Da Silveira, K. S. and Biaou, A. (2013).

Characterization of weathering profile in granite and volcanosedimentary rocks in West Africa under humid tropical climate conditions. Case of the Dimbokro Catchment (Ivory Coast). J Earth Syst Sci. 122(3):841-854.

Leyland, R. C. and Witthüser, K. T. (2008). Regional description of the groundwater chemistry of the Kruger National Park. WRC Report No. KV 211/08. Water Research Commission. Pretoria.

Marshak, S. (2005). Earth: Portrait of a Planet. W. W. Norton \& Company. London. McFarlane, M. J. (1976). Laterite and Landscape. Kent: Academic Press. McKnight, C. (1999). An overview of Archaean geology with a focus on Gauteng and its influences on development. Lecture to SAICE and SAIEG. SRK House, Ilovo. 31 March 1999.

National Department of Housing. (2002). Geotechnical site investigations for housing developments. Generic specification GFSH-2. September 2002.

NWA [National Water Act]. (1998). National Water Act 36 of 1998. Government Printer. Pretoria.

Partridge, T. C. and Maud, R. R. (1987). Geomorphological evolution of southern Africa since the Mesozoic. South African Journal of Geology. 90(2):179-208. Reynolds, W. D. and Elrick, D. E. (1986) A method for simultaneous in situ measurement in the vadose zone of field saturated hydraulic conductivity, sorptivity 
and the conductivity pressure head relationship. Groundwater Monitoring Review. 6(1):84-85.

Righi, D. and Meunier, A. (1995). Origin of clays by rock weathering and soil formation. In: Velde, B. (ed). Origin and mineralogy of clays: clays and the environment. Springer. Germany.

Robb, L. J., Brandl, G., Anhaeusser, C. R. and Poujol, M. (2006). Archaean Granitoid Intrusions. In: Johnson, M. R., Annhaeusser, C. R. and Thomas, R. J. (Eds). The Geology of South Africa. Geological Society of South Africa, Johannesburg/ Council for Geoscience, Pretoria:57-94.

Robins, N., Davies, J. and Farr, J. (2013). Groundwater supply and demand from southern Africa's crystalline basement aquifer: evidence from Malawi. Hydrogeology Journal. 21(4):905-917.

SABS [South African Bureau of Standards]. (1993). Code of Practice: Water Supply and Drainage for Buildings. Part 2: Drainage Installations for Buildings. South African National Standard SANS 10252-2. SABS Standards Division. Pretoria. SABS [South African Bureau of Standards]. (2012a). Soil profiling and rotary percussion borehole logging on dolomite land in southern Africa for engineering purposes. Draft South African National Standard SANS 633. SABS Standards Division. Pretoria.

SABS [South African Bureau of Standards]. (2012b). Geotechnical investigations for township development. Draft South African National Standard SANS 634. SABS Standards Division. Pretoria.

SAICE [South African Institution of Civil Engineering - Geotechnical Division]. (2010). Site investigation code of practice. $1^{\text {st }} \mathrm{Ed}$. Available on the Internet at http://www.geotechnicaldivision.co.za/. 
Scarciglia, F., Le Pera, E. and Critelli, S. (2005), Weathering and pedogenesis in the Sila Grande Massif (Calabria, South Italy): from Field Scale to Micromorphology. Catena. 61:1-29.

Schaetzl, R. J. and Anderson, S. (2005). Soils Genesis and Geomorphology. Cambridge University Press. Cambridge.

Sequeira Braga, M. A., Paquet, H. and Begonha, A. (2002). Weathering of granites in a temperate climate (NW Portugal): Granitic saprolites and arenization. Catena.

49:41-56.

Smit I. P. J., Riddell E. S., Cullum C. and Petersen R. (2013). Kruger National Park Research Supersites: Long-term Research Sites to facilitate Cross-disciplinary Multiscale Learning in a Data-rich Environment. Koedoe. doi:10.4102/koedoe.v55i1.1107. Sparks, B. W. (1971). Rocks and Relief. Longman Group Limited. London.

Titus, R., Beekman, H., Adams, S. and Strachan, L. (Eds.). (2009). The basement aquifers of South Africa. WRC Report No. TT 428/09. Water Research Commission. Pretoria.

Van Rooy, J. L. and Dippenaar, M. A. (2008). The use of index laboratory testing to determine the engineering behaviour of granitic saprolite. Proceedings: Problem Soils in South Africa. 3-4 November 2008, Midrand Gauteng. Geotechnical Division of the South African Institution of Civil Engineering/ South African Institute for Engineering and Environmental Geologists. ISBN 978-0-620-42511-7. Pp35-40. Vegter, J. R. (1995). An explanation of a set of national groundwater maps. Report No. TT 74/95. Water Research Commission. Pretoria.

Venter, F. J. (1986). Soil patterns associated with the major geological units of the Kruger National Park. Koedoe. 29:125-138.

Venter, F. J. and Bristow, J. W. (1986). An account of the geomorphology and drainage of the Kruger National Park. Koedoe. 29:117-124. 
Viana da Fonseca, A., Carvalho, J, Ferreira, C., Santos, J. A., Almeida, F., Pereira, E., Feliciano, J. Grade, J. and Oliviera, A. (2006). Characterisation of a profile of residual soil from granite combining geological, geophysical and mechanical testing techniques. Geotechnical and Geological Engineering. 24:1307-1348.

Villhoth, K. G., Tøttrup, C., Stendel, M. and Maherry, A. (2013). Intergrated mapping of groundwater drought risk in the Southern African Developing Community (SADC) region. Hydrogeology Journal. 21(4):863-885.

Weinert, H. H. (1980). The Natural Road Construction Materials of Southern Africa. Human \& Rousseau. Cape Town.

Witthüser, K. T., Holland, M., Rossouw, T. G., Rambau, E., Bumby, A. J., Petzer, K. J., Dennis, I., Beekman, H, Van Rooy, J. L., Dippenaar, M. and De Wit, M. (2010). Hydrogeology of basement aquifers in the Limpopo Province. WRC Report No. 1693/1/10. Water Research Commission. Pretoria.

Wright, E. P. and Burgess, W. G. (eds.) (1992). The hydrogeology of crystalline basement aquifers in Africa. Geological Society Special Publication No 66. Geological Society. London.

Zaidel'man, F. R. (2007). Lessivage and its relation to the hydrological regime of soils. Erosion Soil Science. 4(2):115-125. 
Appendix A: $\quad$ XRD and XRF data for selected granites (blank cells denote concentrations below detection).

\begin{tabular}{|c|c|c|c|c|c|c|c|c|c|c|c|c|c|c|c|}
\hline $\begin{array}{c}\text { Sample } \\
\text { Nr. }\end{array}$ & SG15F & SG15W & SG73 & SG80 & SG03 & SG01 & SG08 & VP01 & VP01 & VP01 & VP02 & VP04 & VP05 & VP06 & VP07 \\
\hline $\begin{array}{c}\text { Descripti } \\
\text { on }\end{array}$ & $\begin{array}{c}\text { Mate- } \\
\text { kenyane }\end{array}$ & $\begin{array}{c}\text { Mate- } \\
\text { kenyane }\end{array}$ & $\begin{array}{c}\text { SE } \\
\text { Bornhar } \\
\mathrm{dt}\end{array}$ & W Tor & $\begin{array}{l}\text { Stevens } \\
\text { on- } \\
\text { Hamilto } \\
\text { n }\end{array}$ & $\begin{array}{c}\text { Batholit } \\
\text { h }\end{array}$ & $\begin{array}{c}\text { Batholit } \\
\text { h }\end{array}$ & $\begin{array}{c}\text { JDG } \\
\text { Midslop } \\
\text { e }\end{array}$ & $\begin{array}{c}\text { JDG } \\
\text { Midslop } \\
\text { e }\end{array}$ & $\begin{array}{c}\text { JDG } \\
\text { Midslop } \\
\text { e }\end{array}$ & $\begin{array}{c}\text { JDG } \\
\text { Midslop } \\
\text { e }\end{array}$ & $\begin{array}{c}\text { JDG } \\
\text { Midslop } \\
\text { e }\end{array}$ & $\begin{array}{c}\text { JDG } \\
\text { Midslop } \\
\text { e }\end{array}$ & $\begin{array}{c}\text { JDG } \\
\text { Midslop } \\
\text { e }\end{array}$ & $\begin{array}{c}\text { JDG } \\
\text { Midslop } \\
\text { e }\end{array}$ \\
\hline $\mathrm{SiO} 2$ & 75.35 & 74.20 & 68.99 & 72.37 & 75.42 & 72.70 & 78.22 & 74.48 & 75.55 & 71.70 & 74.67 & 75.53 & 73.38 & 69.20 & 74.99 \\
\hline $\mathrm{TiO} 2$ & 0.09 & 0.89 & 0.61 & 0.39 & 0.17 & 0.47 & 0.29 & 0.14 & 0.21 & 0.24 & 0.16 & 0.12 & 0.18 & 0.09 & 0.13 \\
\hline $\mathrm{Al} 203$ & 13.72 & 15.40 & 15.51 & 14.52 & 13.28 & 13.35 & 11.14 & 15.00 & 12.73 & 16.23 & 14.22 & 14.72 & 15.97 & 12.82 & 14.80 \\
\hline Fe2O3 & 1.14 & 4.92 & 3.65 & 3.22 & 1.47 & 3.49 & 1.83 & 1.38 & 3.10 & 2.25 & 1.13 & 1.00 & 1.24 & 0.72 & 0.95 \\
\hline $\mathrm{MnO}$ & 0.01 & 0.07 & 0.08 & 0.04 & 0.02 & 0.05 & 0.02 & 0.03 & 0.13 & 0.02 & 0.02 & 0.01 & 0.05 & 0.02 & 0.05 \\
\hline $\mathrm{MgO}$ & $<0.01$ & 1.11 & 1.08 & 0.69 & 0.15 & 0.63 & 0.04 & 0.31 & 0.18 & 0.46 & 0.26 & 0.16 & 0.18 & $<0.01$ & 0.12 \\
\hline $\mathrm{CaO}$ & 0.45 & 1.83 & 2.35 & 2.28 & 0.81 & 0.75 & 0.54 & 0.02 & $<0.01$ & 0.57 & 0.02 & $<0.01$ & 0.01 & $<0.01$ & 0.00 \\
\hline $\mathrm{Na} 2 \mathrm{O}$ & 3.24 & 4.30 & 4.60 & 4.39 & 3.15 & 1.60 & 1.57 & 3.44 & 2.53 & 3.81 & 3.67 & 3.33 & 2.73 & 2.26 & 3.66 \\
\hline K2O & 5.95 & 3.58 & 2.75 & 2.16 & 5.28 & 3.10 & 4.26 & 3.06 & 3.15 & 1.93 & 4.11 & 5.31 & 4.88 & 7.89 & 3.78 \\
\hline P205 & 0.05 & 0.35 & 0.17 & 0.17 & 0.05 & 0.03 & 0.01 & 0.01 & 0.03 & 0.03 & 0.02 & 0.02 & 0.03 & 0.02 & 0.01 \\
\hline Cr203 & $<0.01$ & $<0.01$ & $<0.01$ & $<0.01$ & $<0.01$ & 0.01 & $<0.01$ & $<0.01$ & 0.01 & $<0.01$ & $<0.01$ & $<0.01$ & 0.01 & $<0.01$ & $<0.01$ \\
\hline $\mathrm{NiO}$ & $<0.01$ & $<0.01$ & $<0.01$ & $<0.01$ & $<0.01$ & 0.01 & $<0.01$ & $<0.01$ & $<0.01$ & $<0.01$ & $<0.01$ & $<0.01$ & $<0.01$ & 0.03 & $<0.01$ \\
\hline
\end{tabular}




\begin{tabular}{|c|c|c|c|c|c|c|c|c|c|c|c|c|c|c|c|}
\hline V205 & $<0.01$ & 0.01 & 0.01 & 0.01 & $<0.01$ & 0.01 & $<0.01$ & $<0.01$ & 0.01 & $<0.01$ & $<0.01$ & $<0.01$ & $<0.01$ & $<0.01$ & $<0.01$ \\
\hline ZrO2 & 0.01 & 0.06 & 0.03 & 0.03 & 0.02 & 0.03 & 0.04 & 0.02 & 0.02 & 0.02 & 0.02 & 0.01 & 0.02 & 0.08 & 0.02 \\
\hline $\mathrm{CuO}$ & $<0.01$ & $<0.01$ & $<0.01$ & $<0.01$ & $<0.01$ & $<0.01$ & $<0.01$ & $<0.01$ & $<0.01$ & $<0.01$ & $<0.01$ & $<0.01$ & $<0.01$ & $<0.01$ & $<0.01$ \\
\hline LOI & 0.32 & -6.84 & 0.71 & 0.37 & 0.34 & 4.56 & 1.64 & & & & & & & & \\
\hline TOTAL & 100.34 & 99.87 & 100.54 & 100.64 & 100.17 & 100.78 & 99.62 & 97.91 & 97.66 & 97.27 & 98.29 & 100.21 & 98.67 & 93.13 & 98.53 \\
\hline $\mathrm{Kl}$ & & 16.41 & & & & & & 14.03 & 0.00 & 20.78 & & & 16.15 & & 7.06 \\
\hline $\mathrm{Dp}$ & & & & 3.09 & & & & & & & & & & & \\
\hline $\mathrm{Hb}$ & & 2.81 & & & & & & & & & & & & & \\
\hline $\mathrm{Bt}$ & & & 6.87 & 6.69 & 4.10 & & & & & & & & & & \\
\hline $\mathrm{Mcl}$ & 31.78 & 5.21 & 6.23 & 11.78 & 25.32 & 22.07 & 24.91 & 9.84 & 16.62 & 5.07 & 20.86 & 26.37 & 20.98 & 38.45 & 13.45 \\
\hline Musc & & 41.43 & & & & 8.97 & & 3.83 & 4.24 & 3.96 & 3.97 & 3.36 & 2.55 & 1.64 & 3.07 \\
\hline Plag & 32.26 & 34.14 & 52.16 & 37.53 & 31.83 & 17.75 & 16.26 & 34.46 & 28.24 & 39.21 & 34.58 & 33.10 & 27.70 & 31.51 & 37.44 \\
\hline Qtz & 35.96 & & 34.75 & 40.92 & 38.75 & 51.21 & 58.84 & 38.84 & 50.90 & 30.99 & 40.59 & 37.17 & 32.61 & 28.40 & 38.99 \\
\hline TOTAL & 100.00 & 100.00 & 100.01 & 100.01 & 100.00 & 100.00 & 100.01 & 101.00 & 100.00 & 100.01 & 100.00 & 100.00 & 99.99 & 100.00 & 100.01 \\
\hline
\end{tabular}

$\mathrm{Kl}$ - kaolinite; $\mathrm{Dp}$ - diopside; $\mathrm{Hb}$ - hornblende; $\mathrm{Bt}$ - biotite; mcl - microcline; musc - muscovite; plag - plagioclase; qtz - quartz 
Appendix B: $\quad$ Foundation indicator data for all sites (blank cells indicate that the parameter was not recorded).

\begin{tabular}{|c|c|c|c|c|c|c|c|c|c|c|c|c|c|c|c|}
\hline Area & Lithology & Landform & $\begin{array}{c}\text { Sample/ } \\
\mathrm{n}^{1}\end{array}$ & Profile $^{2}$ & Horizon $^{3}$ & $\mathrm{C} \%$ & M\% & S\% & $\mathrm{G} \%$ & LL\% & $\mathrm{PI} \%$ & GM\% & LS\% & USCS & Source 4 \\
\hline SGRS KNP & Nelspruit & & SG81 & 1 & Coll & 6.0 & 9.0 & 63.0 & 22.0 & & NP & & & SM & (a) \\
\hline SGRS KNP & Nelspruit & & SG86 & 1 & Coll & 6.0 & 15.0 & 61.0 & 19.0 & & SP & & & SM & (a) \\
\hline SGRS KNP & Nelspruit & & SG86 & 1 & Coll & 4.0 & 5.0 & 59.0 & 33.0 & 21.0 & 6.0 & & & & (a) \\
\hline SGRS KNP & Nelspruit & & SG87 & 1 & Coll & 8.0 & 17.0 & 65.0 & 9.0 & & NP & & & SM & (a) \\
\hline SGRS KNP & Nelspruit & & SG81 & 1 & PM & 2.0 & 4.0 & 35.0 & 59.0 & & NP & & & SW-SM & (a) \\
\hline SGRS KNP & Nelspruit & & SG86 & 1 & PM & 2.0 & 3.0 & 55.0 & 41.0 & & SP & & & SW-SM & (a) \\
\hline SGRS KNP & Nelspruit & & SG87 & 1 & PM & 7.0 & 11.0 & 51.0 & 31.0 & & $\mathrm{NP}$ & & & SM & (a) \\
\hline SGRS KNP & Nelspruit & & SG81 & 1 & Res & 6.0 & 9.0 & 63.0 & 22.0 & & NP & & & SW-SM & (a) \\
\hline SGRS KNP & Nelspruit & & SG86 & 1 & Res & 2.0 & 2.0 & 38.0 & 59.0 & 20.0 & 5.0 & & & SP & (a) \\
\hline SGRS KNP & Nelspruit & & SG87 & 1 & Res & 6.0 & 9.0 & 47.0 & 39.0 & 17.0 & 4.0 & & & SM\&SC & (a) \\
\hline SGRS KNP & Nelspruit & & SG87 & 1 & Res & 7.0 & 12.0 & 48.0 & 33.0 & & SP & & & SM & (a) \\
\hline SGRS KNP & Nelspruit & & SG88 & 1 & Res & 3.0 & 10.0 & 83.0 & 5.0 & & $\mathrm{NP}$ & & & SM & (a) \\
\hline SGRS KNP & Nelspruit & & SG88 & 1 & Res & 4.0 & 9.0 & 80.0 & 7.0 & & $\mathrm{NP}$ & & & SM & (a) \\
\hline SGRS KNP & Nelspruit & & SG88 & 1 & CW & 4.0 & 8.0 & 70.0 & 18.0 & & SP & & & SM & (a) \\
\hline SGRS KNP & Nelspruit & & SG87 & 1 & HW & 7.0 & 15.0 & 52.0 & 26.0 & 18.0 & 4.0 & & & SM\&SC & (a) \\
\hline SGRS KNP & Nelspruit & & SG82 & 3 & Coll & 21.0 & 20.0 & 56.0 & 4.0 & 47.0 & 25.0 & & & SC & (a) \\
\hline
\end{tabular}




\begin{tabular}{|c|c|c|c|c|c|c|c|c|c|c|c|c|c|c|c|}
\hline SGRS KNP & Nelspruit & & SG82 & 3 & Coll & 18.0 & 19.0 & 56.0 & 7.0 & 46.0 & 22.0 & & & SC & (a) \\
\hline SGRS KNP & Nelspruit & & SG89 & 3 & PM & 7.0 & 15.0 & 38.0 & 41.0 & 37.0 & 14.0 & & & $\mathrm{SC}$ & (a) \\
\hline SGRS KNP & Nelspruit & & SG82 & 3 & Res & 17.0 & 17.0 & 53.0 & 13.0 & 45.0 & 22.0 & & & SC & (a) \\
\hline SGRS KNP & Nelspruit & & SG89 & 3 & HW & 7.0 & 11.0 & 33.0 & 49.0 & 42.0 & 18.0 & & & $\mathrm{SC}$ & (a) \\
\hline SGRS KNP & Nelspruit & & SG89 & 3 & HW & 10.0 & 10.0 & 52.0 & 29.0 & 47.0 & 21.0 & & & SC & (a) \\
\hline SGRS KNP & Nelspruit & & SG01 & 5 & Coll & 9.0 & 20.0 & 69.0 & 2.0 & 25.0 & 11.0 & & & SC & (a) \\
\hline SGRS KNP & Nelspruit & & SG01 & 5 & PM & 26.0 & 18.0 & 54.0 & 2.0 & 46.0 & 22.0 & & & $\mathrm{SC}$ & (a) \\
\hline SGRS KNP & Nelspruit & & SG01 & 5 & Res & 18.0 & 27.0 & 50.0 & 4.0 & 41.0 & 20.0 & & & $\mathrm{SC}$ & (a) \\
\hline SGRS KNP & Nelspruit & & SG01 & 5 & $\mathrm{CW}$ & 8.0 & 23.0 & 52.0 & 17.0 & 35.0 & 11.0 & & & SC & (a) \\
\hline Kiepersol & Nelspruit & & 1 & & Res & 16.6 & & & & 48.2 & 7.1 & & 1.6 & & (b) \\
\hline Kiepersol & Nelspruit & & 1 & & Res & 13.9 & & & & 19.0 & 4.0 & & 1.2 & & (b) \\
\hline White River & Nelspruit & & 12 & & Res & & & & & 44.2 & 14.0 & & 8.4 & & (b) \\
\hline White River & Nelspruit & & 18 & & Res & & & & & 34.0 & 8.1 & & 4.3 & & (b) \\
\hline Bushbuckridge & Nelspruit & & 5 & & Res & 24.0 & & & & 21.5 & 10.6 & 1.3 & 1.4 & & (b) \\
\hline Bushbuckridge & Nelspruit & & 2 & & & 34.5 & & & & 50.5 & 17.4 & 1.2 & 3.2 & & (b) \\
\hline Johannesburg & JDG & & 44 & & Res & 4.4 & & & & 28.2 & 10.8 & & 6.1 & & (b) \\
\hline Johannesburg & JDG & Hillcrest & 8 & & $\begin{array}{c}\text { Coll, PM, } \\
\text { Ferr }\end{array}$ & 10.2 & & & & 31.8 & 12.3 & & & & (c) \\
\hline Johannesburg & JDG & Upper & 41 & & Coll, PM, & 6.3 & & & & 26.9 & 8.9 & & & & (c) \\
\hline
\end{tabular}




\begin{tabular}{|c|c|c|c|c|c|c|c|c|c|c|c|c|c|c|}
\hline & & Slope & & Ferr & & & & & & & & & & \\
\hline Johannesburg & JDG & Midslope & 15 & $\begin{array}{c}\text { Coll, PM, } \\
\text { Ferr }\end{array}$ & 5.4 & & & & 28.4 & 9.3 & & & & (c) \\
\hline Johannesburg & JDG & $\begin{array}{l}\text { Lower } \\
\text { Slope }\end{array}$ & 40 & $\begin{array}{c}\text { Coll, PM, } \\
\text { Ferr }\end{array}$ & 5.5 & & & & 19.1 & 7.2 & & & & (c) \\
\hline Johannesburg & JDG & Floodplain & 3 & $\begin{array}{c}\text { Coll, PM, } \\
\text { Ferr }\end{array}$ & 8.2 & & & & 27.9 & 10.8 & & & & (c) \\
\hline Johannesburg & JDG & Midslope & 13 & Coll & 10.2 & 12.8 & 70.8 & 6.4 & 21.0 & 7.4 & 1.3 & 2.5 & SM (SC) & (d) \\
\hline Johannesburg & JDG & Midslope & 6 & $\mathrm{CW}$ & 8.2 & 15.7 & 59.8 & 16.5 & 19.0 & 6.6 & 1.5 & 2.6 & SM/SC & (d) \\
\hline Johannesburg & JDG & Midslope & 9 & Ferr & 2.7 & 8.0 & 26.9 & 62.3 & 18.9 & 5.1 & 2.3 & 2.4 & $\begin{array}{c}\text { GM } \\
(\mathrm{GC} / \mathrm{SM})\end{array}$ & (d) \\
\hline Johannesburg & JDG & Midslope & 8 & Gran & 4.0 & 6.1 & 54.3 & 35.6 & 25.4 & 8.4 & 2.0 & 3.2 & $\mathrm{SM} / \mathrm{SC}$ & (d) \\
\hline Johannesburg & JDG & Midslope & 7 & Res & 6.7 & 15.3 & 44.4 & 33.0 & 21.3 & 6.0 & 1.6 & 2.3 & SM/SC & (d) \\
\hline
\end{tabular}

Sample number or amount of samples (n) henceforth depicted as mean values

2 Characteristic profile type as discussed for SGRS in KNP

3 Coll - colluvium; PM - pebble marker; Ferr - ferruginized horizons; Res - residual granite; CW - completely weathered granite; Gran - bedrock

4 (a) newly retrieved data SANParks regional mapping; (b) Dippenaar et al. (2006); (c) Van Rooy and Dippenaar (2008); (d) newly retrieved data WRC project K5/2052 